\title{
Correlation between flexural strength and denture base acrylic thickness overlaying implant stud attachments
}

\author{
Khaled N. Alawadhi \\ West Virginia University
}

Follow this and additional works at: https://researchrepository.wvu.edu/etd

\section{Recommended Citation}

Alawadhi, Khaled N., "Correlation between flexural strength and denture base acrylic thickness overlaying implant stud attachments" (2010). Graduate Theses, Dissertations, and Problem Reports. 3041. https://researchrepository.wvu.edu/etd/3041

This Thesis is protected by copyright and/or related rights. It has been brought to you by the The Research Repository @ WVU with permission from the rights-holder(s). You are free to use this Thesis in any way that is permitted by the copyright and related rights legislation that applies to your use. For other uses you must obtain permission from the rights-holder(s) directly, unless additional rights are indicated by a Creative Commons license in the record and/ or on the work itself. This Thesis has been accepted for inclusion in WVU Graduate Theses, Dissertations, and Problem Reports collection by an authorized administrator of The Research Repository @ WVU. For more information, please contact researchrepository@mail.wvu.edu. 
Correlation Between Flexural Strength And Denture Base Acrylic Thickness Overlaying Implant Stud Attachments

Khaled N Alawadhi, D.D.S.

Thesis submitted to the

School of Dentistry

At West Virginia University

in partial fulfillment of the requirements

for the degree of

\author{
Master of Science \\ In \\ Prosthodontics
}

Mark W. Richards, D.D.S., M.S. (Chair)

Mike Bagby, D.D.S., PhD.

Ali Kanawati D.D.S., M.S.

Department of Restorative Dentistry

Morgantown, West Virginia

2010

Keywords: Flexural Strength; Denture Acrylic; Implants Attachments. 


\title{
ABSTRACT \\ Correlation Between Flexural Strength And Denture Base Acrylic Thickness Overlaying Implant Stud Attachments
}

\author{
Khaled N Alawadhi, D.D.S.
}

Objectives: To investigate the effect of acrylic resin thickness and the stud attachment housings on the maximum breaking load, flexural strength and flexural modulus of denture base acrylic resins overlying implant overdenture attachments.

Methods: Fifty-two rectangular specimens were fabricated from high impact denture acrylic resin (Lucitone 199). Forty specimens contain $2.00 \mathrm{~mm}$ height Locator attachment titanium denture caps with black processing males, 12 specimens did not include the denture cap. All specimens were fabricated according to ANSI/ADA SPECIFICATION NO. 12-2002 for testing denture base resin with constant measurements of $64 \mathrm{~mm}$ in length, $10 \mathrm{~mm}$ in width, and variable testing thickness. The specimens were divided into four testing groups according to different thickness of 3,4 , 5 , and $6 \mathrm{~mm}$. each group had 10 specimens with denture cap and 3 specimens without denture cap. Specimens were subjected to 3-point-bending flexural test till fracture using the Instron Universal testing machine. After data collection, mean values and standard deviations were calculated and a two-way analysis of variance (ANOVA) was used to evaluate the effect of denture base thickness, on the flexural strength and modulus of the control and Locator testing specimens.

Results: The data collected showed a positive effect with the use of Locators caps in test specimens on the flexural modulus and maximum displacement. Results showed a positive relationship between maximum load, maximum displacement at break and acrylic thickness. There was no significant effect of different acrylic thicknesses on the flexural strength or flexural modulus.

Conclusions: Evaluation of the available interarch distance, proper diagnosis, and treatment planning is of critical importance to minimize prosthesis complications and failure. Implant-retained overdentures utilizing a low profile stud attachment (Locators by Zest) is a recommended treatment option for patients with compromised interarch space. Implant stud attachment components integrated in denture resin has a positive effect on the flexural modulus. The stiffness of the denture resin increased when Locator caps were contained in the specimens compared to specimens with no caps. There was a positive effect of acrylic thickness on the maximum load at break and maximum displacement. Increase acrylic thickness will lead to higher maximum load and decreased incidence of overdenture fractures. 


\section{DEDICATION}

I would like to dedicate this project to my father Dr. Neama Alawadhi who passed away on January $1^{\text {st }} 2010$. You had shown me through the years the true meaning of love, wisdom, the purpose of life. Thank you for all of the lessons that you have taught me. Everything that I am and all that I will become in this life I truly owe to you. You have Shown me where my future is, but you have never let me forget where I come from and how integral that is to who I am.

Be proud, your kids are and will continue your legacy in life. I love you and you'll be missed as long as we live, may your soul rest in peace in heaven. 


\section{ACKNOWLEDGEMENTS}

I would like to thank the following people for changing and enhancing my life professionally as well as personally:

Dr. Mark W. Richards, for providing me with the opportunity to have partaken in this specialty program. Thank you for always being positive, helpful, and willing to bestow your undying knowledge of Prosthodontics upon me.

More than anything thank you for being a friend and a colleague.

Dr. Mohssen Ghalichebaf, for the inspiration that you have provided in showing me that prosthetics in dentistry can truly change and save a patient's life. Thank you for all that you have taught me through the years and all of the advice that you have shared. Thank for the providing the leadership that we needed in these times of trouble.

Dr. Mike Bagby Thank you for sharing your infinite knowledge and guidance with this research.

Ali Kanawati, for the idea of doing this research project as well as for all of your help.

Dr. Harold Reed, for showing me all of the small details that most would overlook when dealing with esthetics in Prosthodontics. Thank you for sharing your infinite knowledge and teaching me in periodontics and implant dentistry.

All Prosthodontic residents for the insurmountable friendships and support that you have given me for the last two years of my residency. Thank you. 


\section{TABLE OF CONTENTS}

ABSTRACT

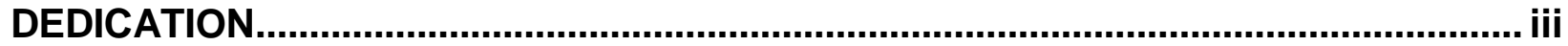

ACKNOWLEDGEMENTS ............................................................................................ iv

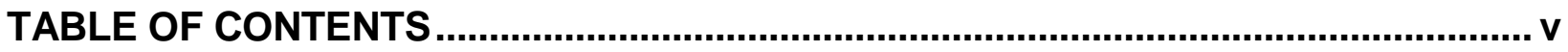

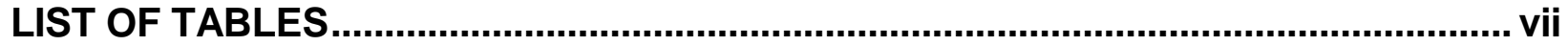

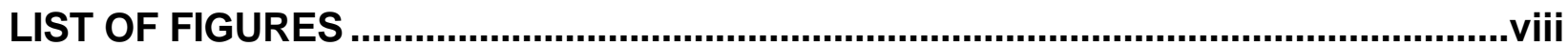

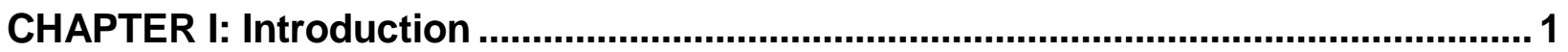

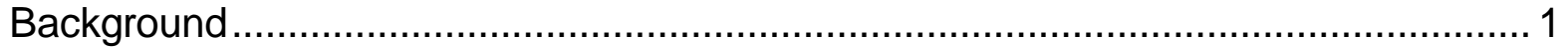

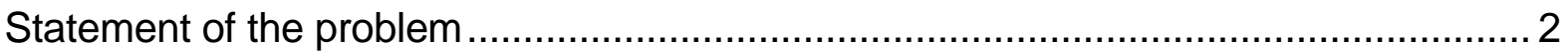

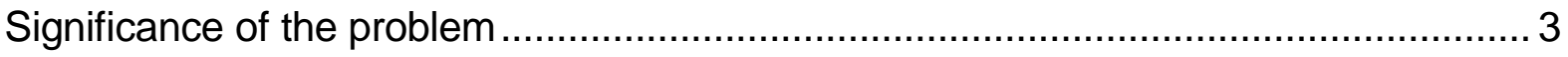

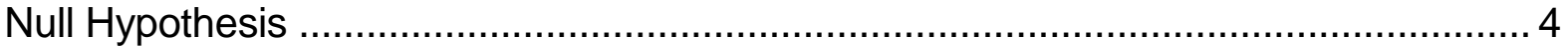

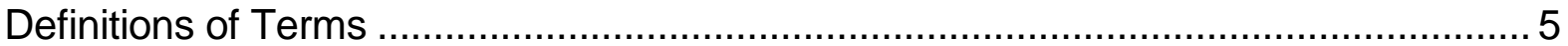

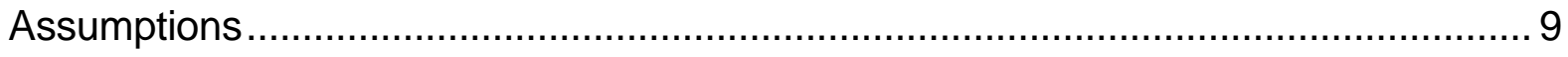

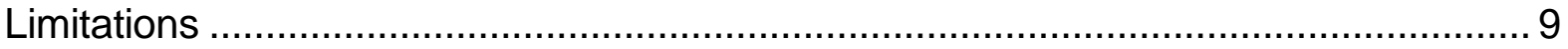

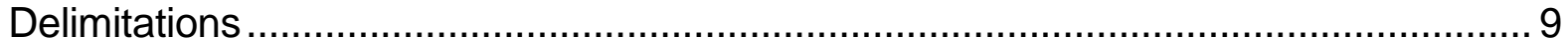

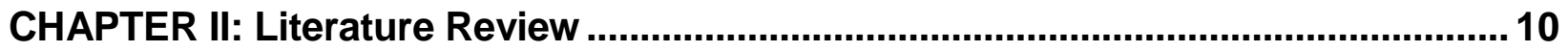

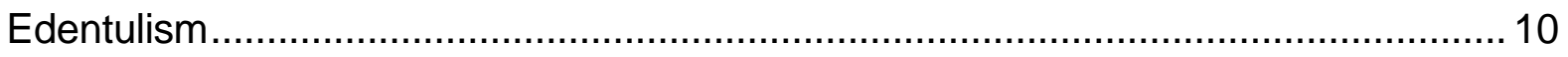

Limitation Of Conventional Complete Dentures.................................................... 12

Tooth supported Overdenture Treatment …...................................................... 13

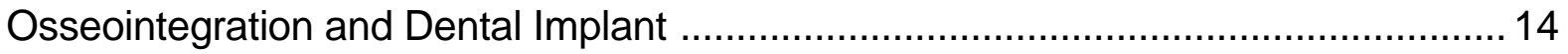

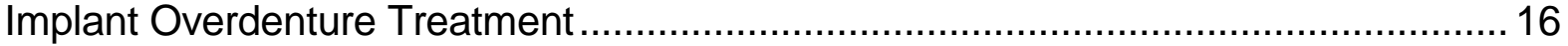

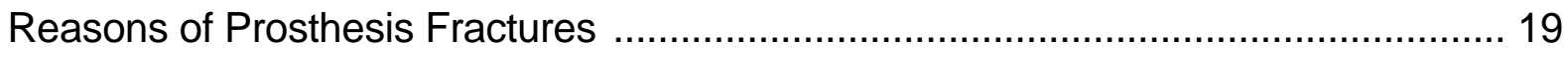

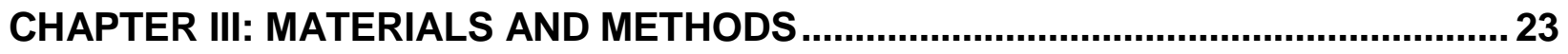

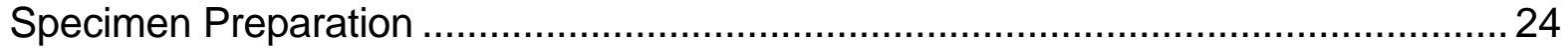

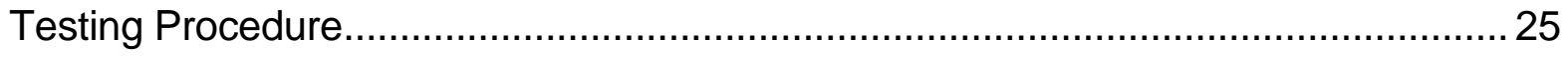

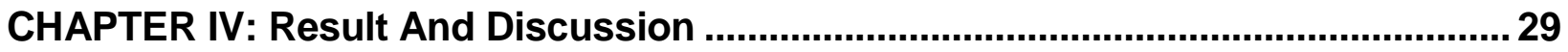

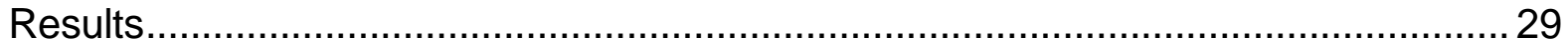




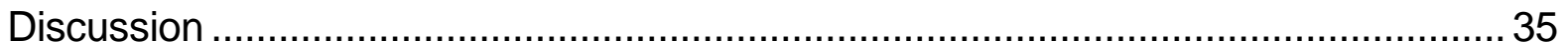

CHAPTER V: Summary And Conclusion ..................................................................... 39

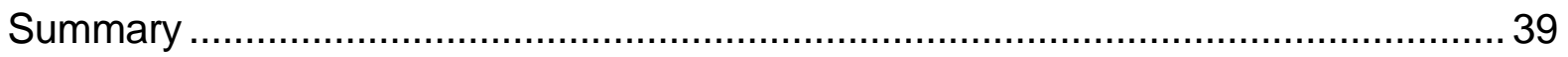

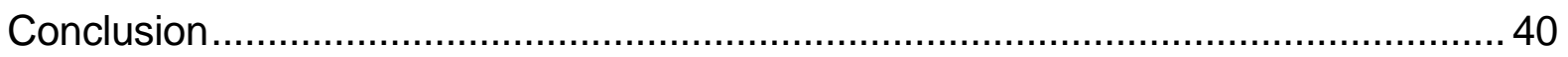

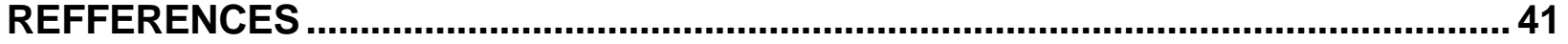

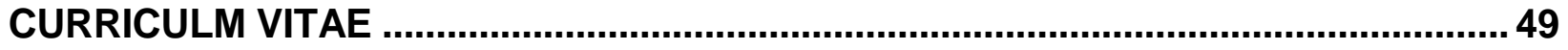




\section{LIST OF TABLES}

Table 1. Breaking Load and Displacement Means.................................................. 30

Table 2. Flexural Strength, Flexural Modulus, and Slope Means ................................ 30 


\section{LIST OF FIGURES}

Figure 1. Fractured Implant Retained Overdenture .................................................. 19

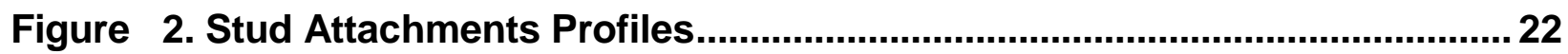

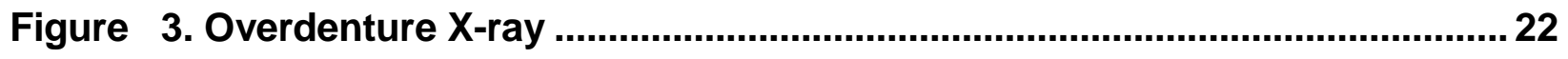

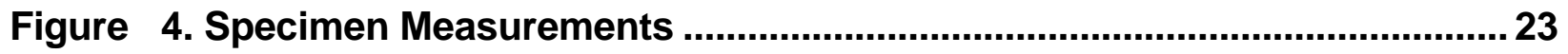

Figure 5. Specimens with Different Acrylic Thickness............................................. 24

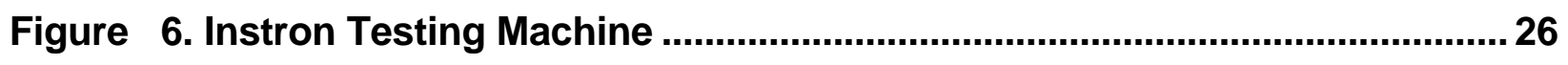

Figure 7. Load Centered in Specimen Center .......................................................26

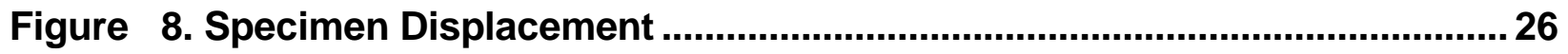

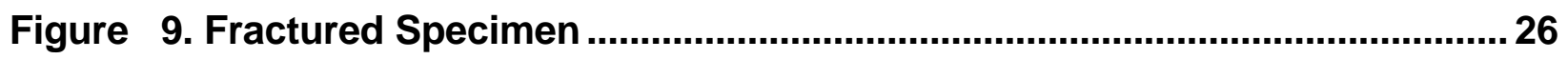

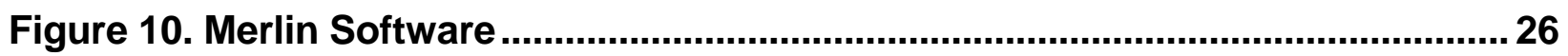

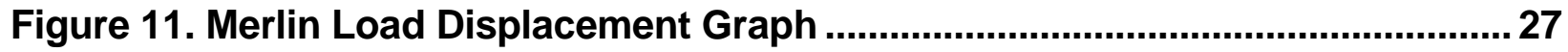

Figure 12. St/Test Least Sq. Flexural Modulus Means \pm SD ...................................... 31

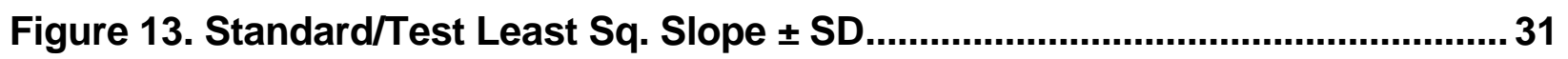

Figure 14. Breaking Load Least Sq. Means \pm SD ...................................................... 32

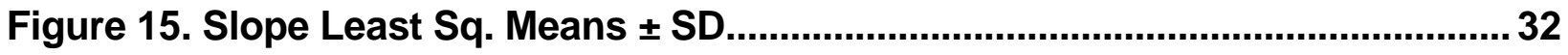

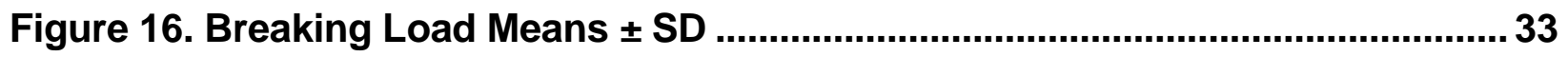

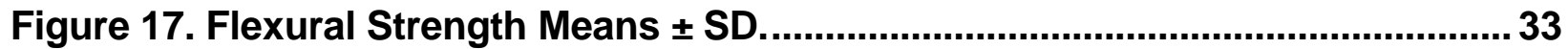

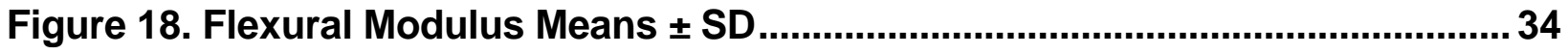

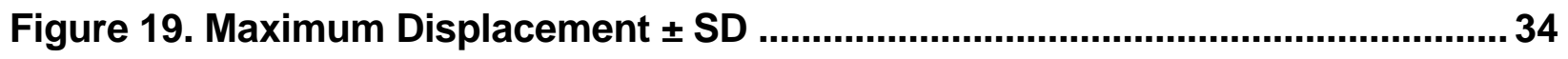




\section{CHAPTER I}

\section{INTRODUCTION}

\section{BACKGROUND}

Edentulism is defined as the absence or complete loss of all natural teeth ${ }^{1}$. It is a significant health problem in the United States; it is one of a few dental conditions for which state-specific data exist. According to the "Healthy People 2010 Objectives for Improving Health", $26 \%$ of the US population between the ages of 65 years and 74 years are completely edentulous. ${ }^{35} \mathrm{~A}$ wide demographic variation exists in the percentages of the population aged 65 and older who are completely edentulous, from a low of 13.9 percent in Hawaii to a high of 47.9 percent in West Virginia. ${ }^{35}$

The sequelae of tooth loss is residual ridge resorption both in the horizontal and vertical direction. This ongoing loss of hard and soft tissue leads to functional, physiological, and psychological challenges that will compromise the treatment success and effect patients' satisfaction. According to World Health Organization criteria, edentulous patients are considered physically impaired disabled, and handicapped. ${ }^{4,35}$

Complete removable dentures are the classic treatment option for the edentulous patient. For successful conventional complete denture treatment, extensive attention to details, diagnosis, and treatment planning is required. Such success is considered an acknowledged challenge by many clinicians, ${ }^{34}$ according to Zarb and Schmitt; patients

perceive denture success as an increase in retention and stability. ${ }^{5}$ Across-arch comparisons indicate mandibular denture treatment produces significantly more 
problems than maxillary denture treatment. Lack of retention was found to be the cause for that difference. ${ }^{6}$ Redford et al, showed that over $50 \%$ of mandibular complete dentures have problems with stability and retention. ${ }^{6}$

The introduction of implant supported overdentures have improved the quality of life for edentulous patients and have contributed significantly to the patient's psychological well-being. ${ }^{7,8}$ Patients report increased satisfaction with the implantretained overdenture rather than conventional complete dentures. ${ }^{9,10}$ The use of 2 implants to retain an overdenture is considered the minimum number necessary to significantly improve the prognosis of mandibular edentulism. ${ }^{9,10,11}$ The retention and stabilization for the overdenture is provided by features of the denture-bearing area and the attachment components, such as bar and clips or stud attachment. ${ }^{12,13,14}$ However, the restoration of the edentulous arch requires a certain amount of vertical space between the opposing arches to ensure adequate denture base thickness for strength, space for the attachments retentive elements, esthetics, and cleanability. ${ }^{15,16}$ Careful pretreatment evaluation of the available interarch space is essential to limit treatment complications such as denture base fracture over attachments housing. ${ }^{16,17}$

\section{Statement of problem}

An implant-retained overdenture requires more treatment planning than a conventional complete denture. An important consideration in fabricating a mandibular overdenture is ensuring sufficient space for the prosthetic components of the implant attachment system. ${ }^{15,16,17}$ Inadequate space for prosthetic components can result in an 
overcontoured prosthesis, excessive occlusal vertical dimension, fractured teeth adjacent to the attachments, attachments separation, and the fracture of the prosthesis, which will result in patient dissatisfaction ${ }^{18,19}$.

\section{Significance of the Problem}

An overdenture retained by two implants placed in the anterior mandible is considered to be the standard of care for edentulous patients who are not satisfied with conventional complete dentures. ${ }^{21,22,23}$ The fabrication and use of this prosthesis requires proper patient selection, proper diagnosis, thorough treatment planning, careful consideration regarding the placement and orientation of the implants, and adequate interarch space for denture base thickness and esthetics. ${ }^{24}$

A common problem associated with implant-retained overdentures is fracture of the denture base over the attachment housing. ${ }^{17-19,24-26}$ The thickness of the overlaying acrylic is critical in resisting the loading forces and fractures. Some authors recommend a minimum thickness of $2.00 \mathrm{~mm}$. However, little scientific evidence is available to support such recommendation. ${ }^{25-33}$

This study investigates the correlation between acrylic resin thickness and flexure strength, and the flexure modulus of denture base acrylic resins overlying the overdenture attachment housing. This knowledge should help dentists determine the acceptable denture base thickness over attachment housing and will comply with the ANSI/ADA Specification No. 12:2002/ISO 1567:2002 for denture base acrylic specifications. 


\section{Null Hypothesis}

One millimeter of heat polymerize high impact denture base acrylic thickness overlaying implant stud attachment component will not meet the ANSI/ADA Specification No. 12:2002/ISO 1567:1999 specification for flexural strength and flexural modulus of denture base acrylic. 


\section{Definition of Terms}

1. Edentulism: without teeth, lacking teeth. ${ }^{1}$

2. Residual Ridge Resorption: a term used for the diminishing quantity and quality of the residual ridge after teeth are removed. ${ }^{1}$

3. Interarch distance: the inter-ridge distance; the vertical distance between the maxillary and mandibular dentate or edentate arches under specified conditions. ${ }^{1}$

4. Denture: an artificial substitute for missing natural teeth and adjacent tissues. ${ }^{1}$

5. Overdenture: any removable dental prosthesis that covers and rests on one or more remaining natural teeth, the roots of natural teeth, and/or dental implants; a dental prosthesis that covers and is partially supported by natural teeth, natural tooth roots, and/or dental implants. ${ }^{1}$

6. Retention: that quality inherent in the dental prosthesis acting to resist the forces of dislodgment along the path of placement. ${ }^{1}$

7. Stability: the quality of a removable dental prosthesis to be firm, steady, or constant, to resist displacement by functional horizontal or rotational stresses. ${ }^{1}$

8. Dental Implant: a prosthetic device made of alloplastic material(s) implanted into the oral tissues beneath the mucosal or/and periosteal layer, and on/or within the bone to provide retention and support for a fixed or removable dental prosthesis. ${ }^{1}$ 
9. Dental Implant System: dental implant components that are designed to mate together. An implant system can represent a specific concept, inventor, or patent. It consists of the necessary parts and instruments to complete the implant placement and abutment components. ${ }^{1}$

10. Attachment: the biochemical/mechanical interconnection between the dental prosthesis and the tissues to which it is attached. ${ }^{1}$

11. Denture base: the part of a denture that rests on foundation tissue and to which teeth are attached. ${ }^{1}$

12. Acrylic resin: pertaining to polymers of acrylic acid, methacrylic acid, or acrylonitrile; for example, acrylic fibers or acrylic resins. Any group of thermoplastic resins made by polymerizing esters of acrylic or methyl methacrylate acids. ${ }^{1}$

13. Acrylic resin base: a denture base made of acrylic resin. ${ }^{1}$

14. ANSIIADA SPECIFICATION NO. 12-2002: This specification classifies denture base polymers and copolymers and specifies their requirements. It also specifies the test methods to be used in determining compliance with these requirements. It further specifies requirements with respect to packaging and making the products and to the instructions to be supplied for use of these materials. This revision is an adoption of the ISO $1567: 1999 .^{81}$

15. Methyl methacrylate resin: transparent, thermoplastic acrylic resin 
that is used in dentistry by mixing liquid methyl methacrylate monomer with the polymer powder. The resultant mixture forms pliable plastic termed dough, which is packed into a mold before initiation of polymerization. ${ }^{1}$

16. Flask: a metal case or tube used in investing procedures. ${ }^{1}$

17. Flasking: the act of investing in a flask: the process of investing the cast and a wax replica of the desired form in a flask preparatory to molding the restorative material into the desired product. ${ }^{1}$

18. Wax boil out: the removal of wax from a mold, usually by heat. ${ }^{1}$

19. Denture resin packing: filling and pressing a denture base material into a mold within a refractory flask. ${ }^{1}$

20. Trial flask closure: any preliminary closure made for the purpose of eliminating excess material and insuring that the mold is completely filled. ${ }^{1}$

21. Denture processing: the means by which the denture base materials are polymerized to the form of a denture: the conversion of the wax pattern of a denture or a portion of a denture into resin or other material. ${ }^{1}$

22. Denture curing: the process by which the denture base materials are hardened to the form of a denture mold. ${ }^{1}$

23. Flexural strength: a mechanical parameter for brittle materials. Is defined as a material's ability to resist deformation under load. The transverse bending test is most frequently employed, in which specimen having either a circular or rectangular across section is bent until fracture using a three point flexural test technique. The flexural strength represents the highest stress experienced within the material at its moment of rupture. ${ }^{1}$ 
24. Flexural modulus: is the ratio of stress to strain in flexural deformation, or the tendency for a material to bend. It is determined from the slope of a stress-strain curve produced by a flexural test and uses units of force per area. ${ }^{1}$ 


\section{ASSUMPTIONS}

In compromised interach distance patients, utilizing low profile stud attachments and a minimum denture base thickness that meets the ADA/ANSI \#12 specifications should reduce the incidents of denture base fracture overlaying the attachment components.

\section{Limitations}

1. Performance variation in machine used in processing acrylic.

2. Human errors when measuring and mixing the denture base acrylic resin.

3. Humidity and air temperature when storing denture resin materials.

4. The testing method applied.

\section{Delimitations}

1. The use of only stud attachment assembly. (Locators by Zest Anchors, Inc., Escondido,CA).

2. The use of only one type of high impact methyl methacrylate resin. (Lucitone 199 denture base by Dentsply Intl, York, Pa).

3. Specimen dimensions will be standardized, and will vary only in the aspect of thickness. 


\section{CHAPTER II}

\section{LITERATURE REVIEW}

\section{Edentulism}

Edentulism is defined as the loss of all permanent teeth ${ }^{1}$; it is the end result of multifactorial process, involving biologic processes such as caries, periodontal disease, pulpal pathology, trauma, and oral cancer, as well as iatrogenic or therapeutic causes such as limited access to care, patient preferences, and third party payments for treatment options. ${ }^{34,35}$

Edentulism has an apparent impact on an individual's quality of life and has been associated with lower levels of satisfaction and a lower morale. ${ }^{21,36-39}$ According to World Health Organization criteria, ${ }^{4,35}$ edentulous patients are considered physically impaired, disabled, and handicapped due to inability to eat and speak effectively, as well as reduction in social activities. ${ }^{40}$ The management of edentulism requires that clinicians examine edentulism as a chronic illness that is incurable, and functionally and psychologically disruptive. ${ }^{34,35}$ Edentulism has a significant link to chronic systemic conditions such as diabetes, cardiovascular conditions, dementia, cancer, asthma. It requires specific management strategies to overcome or limit its disruptive effects. ${ }^{34,35}$ Mignogna and Fedele reported that chronic oral diseases, despite not being life threatening, result in pain and suffering and reduce the overall quality of life. ${ }^{43}$ 
According to National Institute of Dental and Craniofacial Research epidemiological data, approximately $10 \%$ of the US adult population is completely edentulous, ${ }^{2}$ According to Oral Health-Healthy People 2010, the prevalence of edentulism in seniors (aged 65+) has been estimated to be $26 \%$ in the USA, $15-78 \%$ in Europe, $24 \%$ in Indonesia, and $11 \%$ in China. ${ }^{44}$ The estimated number of edentulous individuals ages 18 to 74 using complete denture prostheses in USA is nearly 14 million. ${ }^{6,45}$ With dramatic demographic differences ranging from $13.9 \%$ in Hawaii to $47.9 \%$ in West Virginia. ${ }^{3}$

It is widely accepted that edentulism will not go away in the near future. ${ }^{34}$ Despite the fact that the percentage of completely edentulous patients has declined $10 \%$ per decade for the past 30 years with ninety percent of edentulous patients wearing complete dentures, ${ }^{46}$ the actual number of patients requiring complete dentures is expected to increase from 33.6 million in 1991 to 37.9 million by $2020 .^{46}$ This increase is due to the exponential population growth, increase life expectancy, and continue declining access to dental care. According to Thompson et al, by 2012 there will be a $25 \%$ increase in adult group age 65 and older compared to the year $1997 .{ }^{77}$ Douglas et al, predict that in 2020 there will be a $71 \%$ increase in the adult group age 55 years and older, and that edentulous patients will need or demand an increase of approximately 230,000 units of complete dentures per year. ${ }^{46}$ 


\section{Limitations of conventional complete dentures}

Natural tooth loss is associated with a mild grief reaction: this is found in at least half the edentulous patients and is more common in women than men. ${ }^{47,48}$ For many years the complete tissue supported removable dentures has been regarded as the treatment of choice. Complete dentures have been very beneficial methods for teeth replacement with $70 \%$ overall patient acceptance ${ }^{47,48}$ However, there is percentage of denture patients with limited success with their prostheses and some with no success at all. ${ }^{49}$

Patient's successful accommodation to dentures is an acknowledged challenge to many clinicians. ${ }^{34}$ There is considerable variation among denture patients in respect to complete dentures adaptation. Patient's oral anatomy, social life, education, understanding of edentulism, realistic expectations and attitudes are some of many factors that greatly influence treatment success. Such factors might expedite the adaptation and acceptance or it may cause huge dissatisfaction. ${ }^{34}$

Dissatisfaction with dentures has multiple bases. When considering the selfreported satisfaction regarding complete denture use, patients describe instability, discomfort, decrease in occlusal force, eating difficulties, altered taste sensation, and speaking difficulty as factors that cause dissatisfaction. ${ }^{51-56}$ However, patients have described instability and discomfort as being the main key reasons for dissatisfaction. Across-arch comparisons for mandibular versus maxillary denture use has revealed that stability and comfort are the features that distinguish maxillary denture acceptance from 
mandibular denture dissatisfaction. ${ }^{6}$ Redford et al showed that over $50 \%$ of mandibular complete dentures have problems with stability and retention. ${ }^{6}$

\section{Tooth supported Overdenture Treatment}

In attempt to resolve complete denture complications, the concept of tooth supported overdentures was first introduced at the World Dental Congress in 1861 by Butler, Roberts, and Hays. ${ }^{57,58}$ The current concept of the overdenture was presented at the American Dental Association annual meeting in $1970.57,58$ The glossary of prosthodontics defines overdentures as any removable dental prosthesis that covers and rests on one or more remaining natural teeth, the roots of natural teeth, or dental implants. ${ }^{1}$

The key factor for successful tooth supported overdentures is the effective endodontic treatment that allow for a shortened dental crown, which creates adequate space for the overlying artificial denture tooth and denture base. Moreover, the shortened crown also changes the crown to root ratio thus the reduced mobility of the root and improved bone support. ${ }^{58}$

Tooth supported overdentures have certain advantages and disadvantages. Among advantages is the preservation of alveolar bone. In a five year period follow up, vertical bone loss in overdenture patients was $0.6 \mathrm{~mm}$ comparing to the bone loss of 5.0 $\mathrm{mm}$ in complete denture ${ }^{58,59}$ Also, stability and support of the overdenture is enhanced in comparison with a conventional complete denture. In addition, sensory feedback of the periodontal receptors is maintained and masticatory performance is enhanced. ${ }^{58,60}$ The chewing efficiency of patients with complete denture was measured at $59 \%$, and 
patients with overdentures at $79 \%$ compared to patients with full dentition. ${ }^{58,59}$. Disadvantages of the tooth supported overdenture treatment include the need for root canal treatment, which necessitate additional time and costs and the possibility of failure as result of caries or periodontitis affecting retained roots and root fracture. ${ }^{58}$

\section{Osseointegration and Dental Implant}

In 1952, Per-Ingvar Brånemark, Swedish orthopedic surgeon conducted an experiment where he implanted optical titanium chamber to study blood flow in rabbit bone. At the conclusion of the experiment, he and his team found that titanium chamber placed into the rabbits could not be removed from the bone after a period of healing. Brånemark termed the discovery "osseointegration," and saw the possibilities for human benefits. In 1965 Brånemark, placed his first titanium dental implant into a human volunteer at Gothenburg University in Sweden . 5,61

In 1978, the first Dental Implant Consensus Conference was held at Harvard University, in that conference retrospective data on dental implants were collected and analyzed and criteria and standards for implant dentistry were first established. ${ }^{61}$

In 1982 at the Toronto Conference on Osseointegration in Clinical Dentistry, Brånemark presented his discovery of osseointegration, and the results of his 15 years of human and animal research. The Toronto conference brought widespread recognition to the Brånemark implant methods and materials..$^{5,61}$ 
The glossary of prosthodontic terms defines an implant as "a prosthetic device or alloplastic material implanted into the oral tissues beneath the mucosal or/and periosteal layer, and/or within the bone to provide retention and support for a fixed or removable prosthesis". ${ }^{1}$

Several types of implants have been used throughout history. They include endosteal Implants that are placed into the bone, ${ }^{61-64}$ subperiosteal implants that are placed on or upon the bone ${ }^{61-64}$ and transosteal implants that are placed through the bone. ${ }^{63}$ Branemark's research led to the development and introduction of titanium root form implants. ${ }^{64}$ This type of endosseous implant has become the most widely used implant in the world.

Several designs of the implant prosthesis have been used in the rehabilitation of the edentulous arch. These designs have been classified by the nature of the support provided to the prosthesis: implant-supported fixed prosthesis, implant-supported removable overdenture, and an implant-retained and tissue-supported removable overdenture. In the first 2 options, the dental prosthesis is completely supported by dental implants. These designs require multiple well distributed implants and sophisticated fabrication protocols that usually translate into a higher cost of treatment. The implant-retained overdenture is supported by both implant and mucosa and generally requires fewer implants when compared with the totally implant supported prosthesis design. Fewer implants and removable prosthesis offer a less complex and less expensive option for an edentulous patient. The most common protocol used in the implant-retained mandibular overdenture treatment includes placement of 2 implants in the anterior region of the mandible. ${ }^{76,78,79}$ 


\section{Implant Overdenture Treatment}

Branemark and coworkers research present a solution for edentulism, and helped endosseous dental implants to be considered as the preferable option for edentulous treatment. In Montreal Canada the attendees at 2002 McGill Consensus Conference concluded that the available evidence suggest the restoration of the edentulous mandible with a conventional denture is no longer the most appropriate firstchoice prosthodontic treatment and the mandibular overdenture retained by 2 implants is the first-choice standard of care. ${ }^{23}$

Implant-retained overdentures offer many practical advantages over conventional complete dentures and tooth supported overdentures. These include decreased bone resorption; increase stability and retention, better esthetics, improved phonetics, better occlusion, increase masticatory function, maintenance of the occlusal vertical dimension, and overall improvement of patient's self confidence and quality of life. ${ }^{34}$

Direct relationship has been shown between prosthesis retention, stability, and patient satisfaction. ${ }^{65}$ Patient satisfaction improved when prosthesis retention and stability increased. Mandibular implant overdenture treatment shows a significant increase in retention and stability compared to conventional mandibular complete dentures. Meijer et al found that, after 5 years, patients with mandibular overdentures retained by 2 implants had higher satisfaction scores than complete denture patients. ${ }^{10}$ Raghoebar et al, confirmed this finding in another randomized study with complete denture patients who had pre-prosthetic vestibuloplasty. ${ }^{65}$ 
Furthermore, it was evident when implants were placed into the anterior aspect of edentulous mandibles; minimum anterior residual ridge resorption was detected. ${ }^{13,25}$ In fact, when conventional complete dentures are worn, substantial bone resorption occurs beneath the dentures ${ }^{66}$ and this bone loss is about fourfold the amount of bone change that occurs adjacent to dental implants that are used with overdentures. ${ }^{13,25}$

In addition, longitudinal studies have shown that a mean yearly alveolar ridge height reduction of $0.4 \mathrm{~mm}$ can be expected in the edentulous anterior mandible, resulting from physiological changes. ${ }^{45}$ As well, the rate of resorption is 4 times greater in the mandible, compared with the maxilla. ${ }^{45}$ In comparison, Quirynen et al, found the mean annual marginal bone loss to be $0.9 \mathrm{~mm}$ during the first year after implant placement and $0.1 \mathrm{~mm}$ in following years. ${ }^{67,68}$ Jemt et al, reported $100 \%$ cumulative success rate for overdentures supported by 2 implants; the mean marginal loss was 0.5 mm during a 5-year period. ${ }^{13,25}$ The data are significant when considering the ability of implants to preserve alveolar bone.

The retention and stabilization for the implant-retained overdentures are provided by features of the denture bearing area and the attachment components, which are either bars or individual stud attachments. ${ }^{24}$ Several clinical studies have compared individual implants with stud attachments to implants connected by a bar. Individual implants with stud attachments have had the same favorable clinical results in the mandible as rigidly splinted implants. Some of the advantages of stud attachments in comparison to bar attachment include less cost, less technique sensitive, less dependent on implant position, easier to clean, easier to replace, control the retention 
amount, and requires less inter-occlusal space ${ }^{69} \mathrm{~A}$ study of photoelastic stress patterns indicated that individual implants with stud attachments transferred less stress to the implants than the design that used 2 implants connected by a bar. ${ }^{69}$

Although implant-retained overdentures therapy is extremely successful and have become the standard of care for edentulism, they are not without complication. ${ }^{34}$ It is important to have a working knowledge of the treatment procedure and what complications can occur during the fabrication and insertion of the prosthesis. Such knowledge aids in treatment planning, communicating with the patient, informed consent, and post treatment care of the implants and prostheses. ${ }^{34}$

An important consideration in fabricating a mandibular overdenture is ensuring sufficient space for the prosthetic components of the implant attachment system. The restoration of the edentulous arch requires a certain amount of vertical space between the opposing arches to ensure adequate denture base thickness, space for the attachments retentive elements, esthetics, and cleanse-ability. Careful pretreatment evaluation of the available interarch space is essential to limit treatment complications. As inadequate space for prosthetic components can result in an over-contoured prosthesis, excessive occlusal vertical dimension, fractured teeth adjacent to the attachments, attachments separating from the denture, fracture of the prosthesis, and overall patient dissatisfaction. ${ }^{16,24}$ 


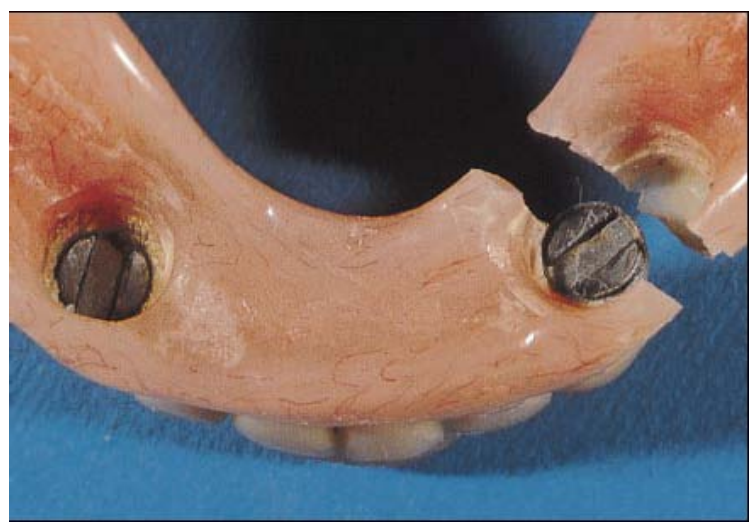

Figure 1. Fractured Implant Retained Overdenture

The estimated interarch space required for an implant-retained overdenture utilizing the lowest profile stud attachment available (Locator attachment) from the implant shoulder to the superior surface of the acrylic resin is approximately $7-8 \mathrm{~mm}$; two to 3 millimeters of soft tissue thickness is generally present above the implant, the total height of the attachment components (abutments plus caps) is $3.17 \mathrm{~mm},{ }^{70}$ and 2 $\mathrm{mm}$ of acrylic resin above the attachment. ${ }^{17,18}$ The minimum horizontal space requirement is $9.0 \mathrm{~mm}$, as the width of the attachment is $5.0 \mathrm{~mm}$ and $2.0 \mathrm{~mm}$ of acrylic resin is required on either side. ${ }^{18}$

The resistance to fracture of acrylic resin denture depends on, among other factors, flexural strength and the thickness of the denture base especially over the attachment housing. ${ }^{17,18,24}$ 


\section{Reasons of Prosthesis Fractures}

Fractures of implant overdentures resin bases occur because of the increased force exerted by patients, by the stress concentration produced when retentive mechanisms are incorporated in the prostheses, and by a resin thickness that is not sufficient to resist the forces placed on the prosthesis. According to Goodacre et al, fractures of implant overdentures and resin prosthesis bases occur in $12 \%$ of the prostheses. In 10 reported studies, 69 Of 570 (12\%) overdentures were fractured due to insufficient denture base thickness. Walton et al reported that $5.8 \%$ of removable implant-supported prosthesis repairs $(n=137)$ involved fractures in the acrylic resin. ${ }^{71,72,73}$ Chaffee et al, reported that 4 of 58 patients (6.9\%) required 12 mandibular overdenture repairs due to resin fracture, primarily in the midline ${ }^{73,74}$ Fractures of the opposing prosthesis were also noted in $12 \%$ of the prostheses (20 of 168 prostheses

were fractured). ${ }^{26,32}$ The range of fracture was from $4 \%$ to $40 \%$. Most of the fractures (12 of 20) were found in opposition to implant overdentures. ${ }^{26,32}$

Potential solutions to the inadequate vertical space include alveoloplasty surgery at the time of implant placement, fabricating the overdenture from high impact acrylic resin, selection of the implant attachment system with a minimal height (Figure 2) or incorporation of the metal-reinforcing framework into the overdenture. ${ }^{75,76}$.

The ideal denture base material should possess several key physical attributes. Some of these properties include biocompatibility, good esthetics, high bond strength with available denture teeth, radiopacity, ease of repair, and should possess adequate 
physical and mechanical properties. ${ }^{82}$ The denture base must be strong enough to allow the prosthesis to withstand functional and parafunctional masticatory forces. Many different materials have been used for denture bases. Historically materials such as bone, wood, ivory, and vulcanized rubber were utilized; now poly methyl methacrylate (PMMA) is used. ${ }^{82}$ New materials such as polystyrene and light-activated urethane dimethacrylate have been developed, but PMMA remains the preferred material for removable complete and partial prostheses. ${ }^{82}$ The popularity of PMMA materials is based on its low cost, relative ease of use, and reliance on simple processing equipment. $^{82}$

Fractures in acrylic dentures can result from impact or bending forces. Impact forces typically are created during an accidental fall of the denture. Bending forces are developed mainly during mastication because of poor adaptation of the denture to the underlying supports, improper occlusion, excessive masticatory forces, or denture deformation during use. Those long-term bending forces will contribute fatigue of the material. ${ }^{83}$ The use of strong resins is critical, variety of physical and mechanical properties can be used to assess the strength of denture materials; flexural strength, the force needed to deform the material to fracture or irreversible yield, flexural modulus; a measure of the stiffness of a material, and the distance a specimen can be deformed before failure are parameters of the denture resin strength. ${ }^{83}$ Given the function of a denture base in a removable prosthesis, high flexural strength, and flexural modulus would help resist forces in function leading to a longer clinical service life for the prosthesis. According to ISO standard (1567:2002), the flexural strength and modulus 
for heat polymerized denture base acrylic resin are targeted to be not less than $65 \mathrm{MPa}$ and 2000 MPa respectively. ${ }^{81}$

Fracture of the acrylic resin denture base, whether for a conventional or implant prosthesis, can be an inconvenient complication. It has been suggested that a minimum of $2 \mathrm{~mm}$ of acrylic resin will be sufficient to withstand occlusal forces. ${ }^{17,18}$ However, in clinical survey of 27 patients wearing implant overdenture retained by 2 implants performed at WVU school of dentistry in 2010, the mean thickness of acrylic resin overlaying the attachment housing was $1.3 \mathrm{~mm}$, with 30 of the 54 (55\% percent) readings had an acrylic thickness of $1 \mathrm{~mm}$ or less. This study investigated the correlation between high impact acrylic resin thickness, flexure strength, and flexure modulus of denture base acrylic resins overlaying the overdenture stud attachment housing. The objective of this study was to determine the minimum acceptable denture base thickness within the ANSI/ADA SPECIFICATION NO. 12-2002 for denture base resin (Figure 3).

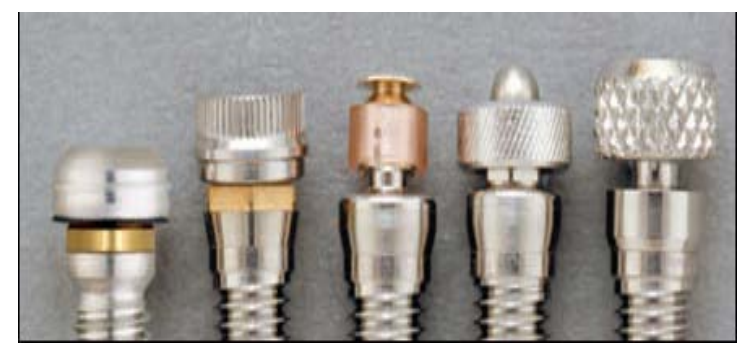

Figure 2. Stud Attachment Profile

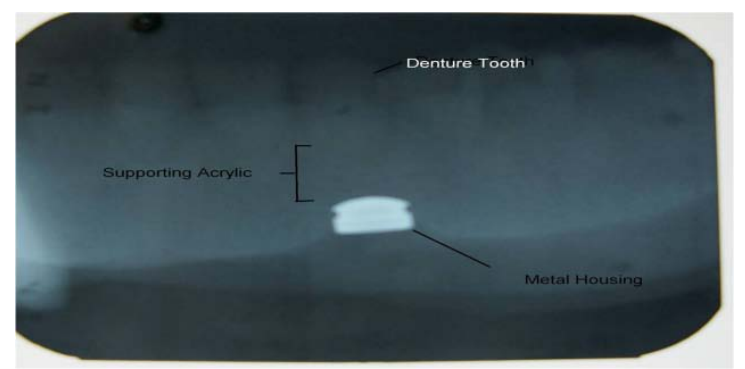

Figure 3. X-ray of Overdenture 


\section{CHAPTER III}

\section{Materials and methods}

High impact heat cured polymethyl methacrylate (PMMA) resin (Lucitone 199, Dentsply Intl, York, Pa) was used to fabricate fifty-two rectangular specimens (Figure 4). Forty specimens contain $2.00 \mathrm{~mm}$ height Locator titanium denture cap, 12 specimens did not include the denture cap. All specimens were fabricated with constant measurements of $64 \mathrm{~mm}$ in length, $10 \mathrm{~mm}$ in width, and variable testing thickness. The specimens were divided into four groups according to the different thickness of $3,4,5$, and $6 \mathrm{~mm}$ (Figure 5). Each group $(\mathrm{n}=13)$ had 10 specimens with denture caps and 3 specimens without denture caps.

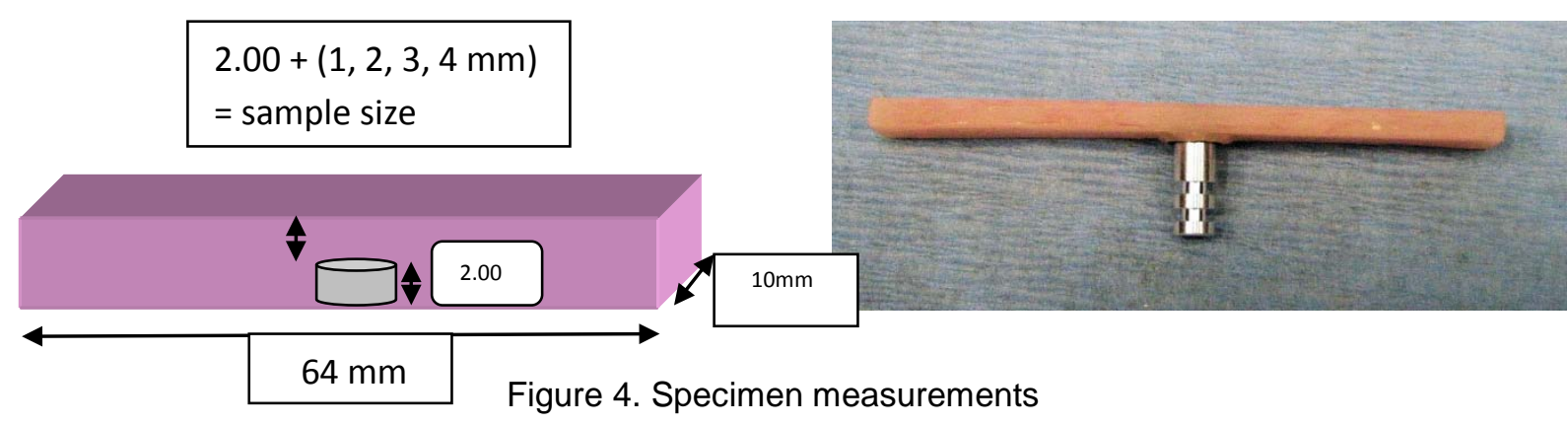




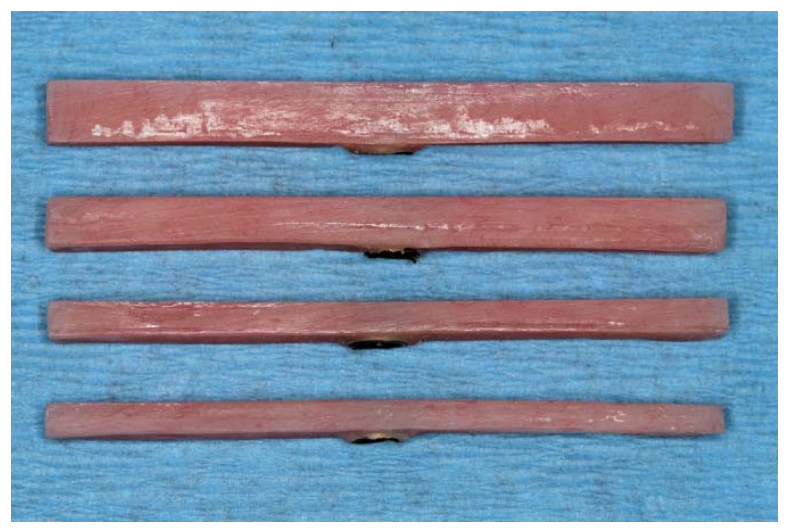

Figure 5. Specimens with Different Acrylic Thickness

\section{Specimen preparation}

Wax master patterns (Modern Material Shur Wax® X-Hard, Heraeus Kulzer South Bend, IN) were fabricated to the recommended measurements and were individually duplicated with high-viscosity silicone (CMP Industries, Albany, NY). Those silicone molds were used to fabricate multiple wax patterns. Patterns were invested with low expansion, fast setting dental stone (Whip Mix, Louisville, KY) in the lower half of the denture flask first, this was allowed to set for half an hour and a single layer of separating medium was applied. A second pour was made with the same stone and the flask was held in compression till the final set of dental stone. After the stone was set, the flasks were de-waxed at $100^{\circ} \mathrm{C}$ for 5 minutes. High impact denture acrylic resin (Lucitone 199. Dentsply Intl. York, Pa) was mixed according to the manufacture recommended ratio of $42 \mathrm{~g}$ polymer to $13 \mathrm{ml}$ monomer; the mixture was sealed in a glass jar for 9 minutes until a doughy consistency was reached. Before packing, all stone surfaces were coated with an alginate separator (Al-cote) and allowed to dry. The acrylic dough was then packed into the flask in slight excess and pressed by hydraulic 
press with load of $3000 \mathrm{lbs}$. the excess was removed by trial packing procedure with a polyethylene sheet used as separator. Before final closure of the flask,the separating polyethylene sheet was removed, excess acrylic resin was removed to insure metal- tometal contact of the flask halves, and final pressed for 5 minutes. The flasks were immersed in water and processed in an automatic polymerization unit (Hanau curing unit) at $74^{\circ} \mathrm{C}$ for 9 hours. After polymerization, all flasks were allowed to bench cool for 2 hours. Specimens were deflasked, and each specimen was finished using 220 grit sandpaper (3M, St. Paul, MN) with 3 strokes in each side. Minimal finishing and polishing was required and care was taken to maintain low heat during the procedure. All specimens were stored in distilled water at $37^{\circ} \mathrm{C}$ for 48 hours prior to testing.

\section{Testing procedure}

Specimens were submitted to 3-point flexure test (ISO 1567:2002 Specifications for denture base polymers) using an Instron Universal testing machine (5500 series, instron corp., Canton, MA, USA) operating at a crosshead speed of $5 \mathrm{~mm} / \mathrm{min}$ with a span length support of $50 \mathrm{~mm}$ (Figure 6). Specimens were set wet from the storage container directly onto the testing apparatus. The load was applied centrally on the specimens until fracture occurred (Figure7,8,9). Data were collected using Merlin series IX software (Figure 10). The Load was recorded in Newton's (N) and the displacement in millimeters (mm) (Figure 11). 


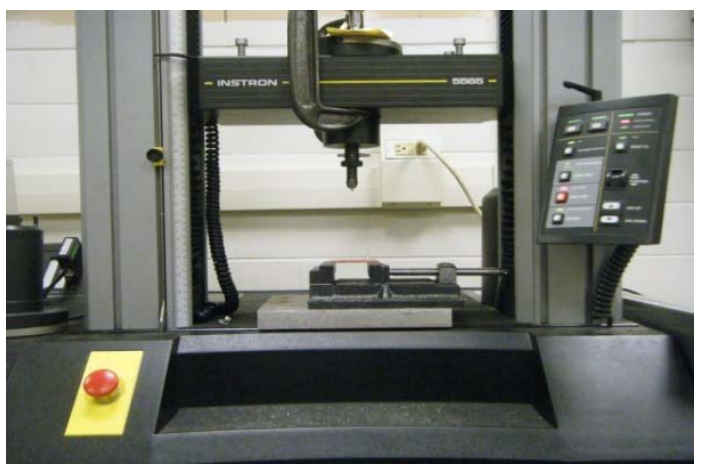

Figure 6. Instron Testing Machine

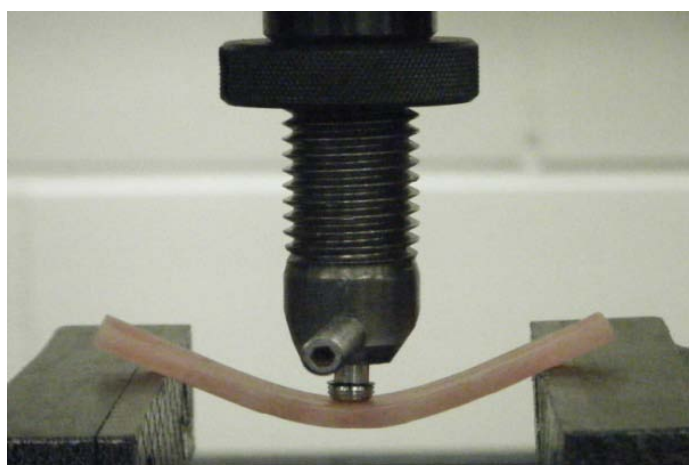

Figure 8. Specimen Displacement

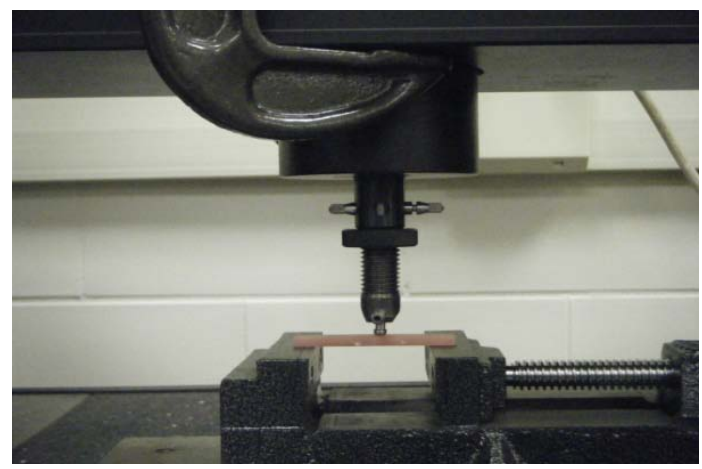

Figure 7. Load centered in specimen center

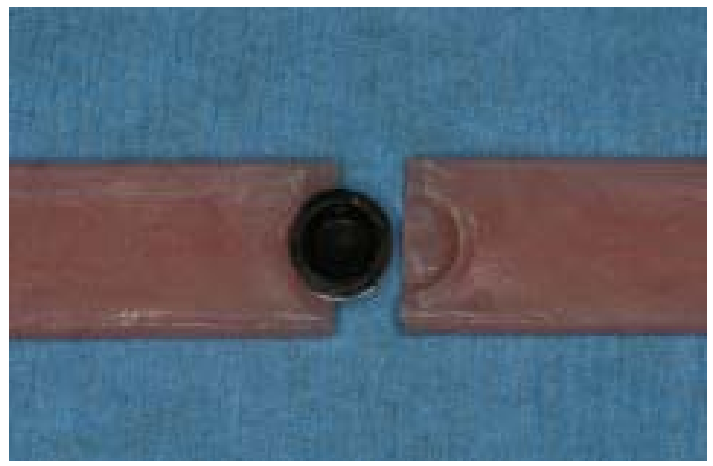

Figure 9. Fractured Specimen

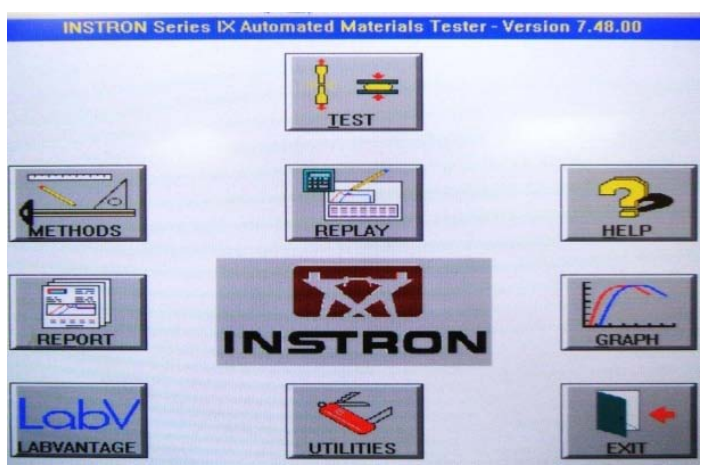

Figure 10. Merlin Software 


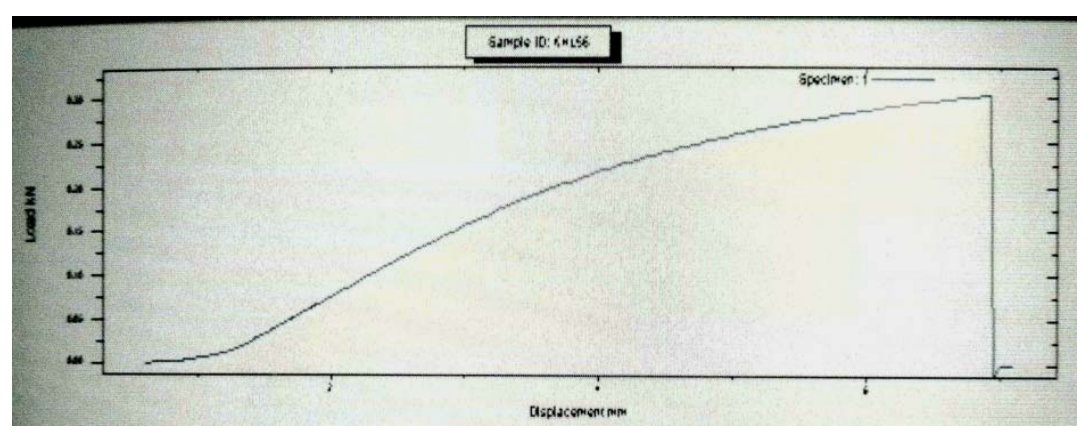

Figure 11. Merlin Load Displacement Graph

The flexural strengths $(\sigma)$ were calculated per the following formula to yield Mega Pascal (MPa) units ${ }^{81}$ :

$$
\sigma=\frac{3 F L}{2 b d^{2}}
$$

$\mathbf{F}$ is maximum load before fracture, $\mathbf{L}$ is span length between the supporting points $(50 \mathrm{~mm}), \mathbf{b}$ is specimen width $(10 \mathrm{~mm})$ and $\mathbf{d}$ is specimen thickness $(3,4,5$, and $6 \mathrm{~mm})$.

The flexural modules $\left(E_{f}\right)$ were calculated per the following formula to yield Mega Pascal (MPa) units ${ }^{81}$ :

$$
E_{f}=\frac{L^{3} m}{4 b d^{3}}
$$

$\mathbf{m}$ is the slope of the initial straight line portion of the load displacement curve, $\mathbf{L}$ is span length between the supporting points $(50 \mathrm{~mm}), \mathbf{b}$ is specimen width (10 $\mathrm{mm})$ and $\mathbf{d}$ is specimen thickness $(3,4,5$, and $6 \mathrm{~mm})$. 
All specimens' results were compared to the ANSI/ADA SPECIFICATION NO. 12 minimum specifications:

\section{Flexural strength:}

The flexural strength shall be not less than $65 \mathrm{MPa}$ for heat activated denture base resin. $^{81}$

\section{Flexural modulus:}

The flexural modulus of the processed polymer shall be at least $2000 \mathrm{MPa}$ for heat activated denture base resin. ${ }^{81}$

After data collection, mean values and standard deviations were calculated and a two-way analysis of variance (ANOVA) was conducted to the collected data to investigate the effect of denture base thickness and attachment caps, on the flexural strength and flexural modulus of the standard (no Locator caps) and Locator testing specimens (with Locator caps). 


\section{CHAPTER IV}

\section{Results}

Table 1 and Table 2 summarize the mean values of the maximum load at break, maximum displacement, slope, flexural strength and flexural modulus between the different thickness groups. Two-way ANOVA analysis of variance indicated that there were significant differences between standard specimens (no Locator caps) and test specimens (with Locator caps) in terms of flexural modulus $(p=0.0009)$ (Figure12) and slope $(p=0.0353)$ (Figure13). Maximum breaking load and flexural strength did not show significant difference $(p=0.242$ and $p=0.640$, respectively) (Figure $16 \& 17)$. The highest flexural modulus value was recorded for the $3 \mathrm{~mm}$ test group (3140 $\pm 89.3 \mathrm{MPa})$ and the lowest was recorded for the $5 \mathrm{~mm}$ standard group $(1398 \pm 67.7 \mathrm{MPa})$ (Figure12). The highest slope was recorded for $6 \mathrm{~mm}$ test group $(161.4 \pm 5 \mathrm{~N} / \mathrm{mm})$ and the lowest was recorded for $3 \mathrm{~mm}$ standard group $(21.4 \pm 0.7 \mathrm{~N} / \mathrm{mm}$ ) (Figure13). The highest displacement at break was recorded for the $3 \mathrm{~mm}$ standard group $(9.76 \pm .7 \mathrm{~mm})$ and the lowest was recorded for the $6 \mathrm{~mm}$ testing group $(3.81 \pm .5 \mathrm{~mm}$ ) (Figure19).

Comparison between test specimens (with Locator caps) with different thicknesses revealed statistical significant difference in term of breaking load ( $p=<$ $.0001)$ and slope $(p=<.0001)$. The $6 \mathrm{~mm}$ test specimens group breaking load mean was $(416 \pm 50 \mathrm{~N})$ compared to the $3 \mathrm{~mm}$ test specimen group $(119 \pm 19 \mathrm{~N})$, nearly fourfold the $3 \mathrm{~mm}$ group breaking load (Figure14). The $6 \mathrm{~mm}$ test specimens group 
slopes mean was (161.3 $\pm 4.9 \mathrm{~N} / \mathrm{mm})$ compared to $3 \mathrm{~mm}$ test specimen group (26.7 \pm 3.8 $\mathrm{N} / \mathrm{mm}$ ) (Figure15). There was no significant effect of specimen thickness on flexural strength and modulus when comparing different thickness test specimen (with Locator caps) groups (Figure17\&18). Overall, all test specimen (Locator caps) groups fulfilled the minimum requirement of the ADA/ANSI specification \#12 for denture base resin for flexural strength (65 MPa) and flexural modulus (2000 MPa).

\begin{tabular}{|c|c|c|c|c|}
\hline \multirow{2}{*}{ Sample } & \multicolumn{2}{|c|}{ Breaking Load $\mathrm{N} \pm$ SD } & \multicolumn{2}{c|}{ Displacement $\mathbf{m m} \pm$ SD } \\
\hline & $\begin{array}{c}\text { Standard } \\
\text { (no caps) } \mathrm{n}=3\end{array}$ & $\begin{array}{c}\text { Test } \\
\text { (w/caps) } \mathrm{n}=10\end{array}$ & $\begin{array}{c}\text { Standard } \\
\text { (no caps) } \mathrm{n}=3\end{array}$ & $\begin{array}{c}\text { Test } \\
\text { (no caps) } \\
\text { n=10 }\end{array}$ \\
\hline $3 \mathrm{~mm}$ & $106 \pm 4$ & $119 \pm 19$ & $9.76 \pm .3$ & $7.33 \pm .8$ \\
\hline $4 \mathrm{~mm}$ & $228 \pm 33$ & $184 \pm 27$ & $7.46 \pm .3$ & $6.01 \pm .4$ \\
\hline $5 \mathrm{~mm}$ & $257 \pm 10$ & $296 \pm 66$ & $6.43 \pm .3$ & $5.25 \pm .4$ \\
\hline $6 \mathrm{~mm}$ & $398 \pm 12$ & $415 \pm 50$ & $5.13 \pm .2$ & $3.81 \pm .2$ \\
\hline
\end{tabular}

Table 1. Breaking Load and Displacement Means

\begin{tabular}{|c|c|c|c|c|c|c|}
\hline Sample & \multicolumn{2}{|c|}{ Flexural Strength MPa \pm SD } & \multicolumn{2}{c|}{ Flexural Modulus MPa \pm SD } & \multicolumn{2}{c|}{ Slope N/mm \pm SD } \\
\hline & $\begin{array}{c}\text { Standard } \\
\text { (no caps) } n=3\end{array}$ & $\begin{array}{c}\text { Test } \\
\text { (w/caps) } n=10\end{array}$ & $\begin{array}{c}\text { Standard } \\
\text { (no caps) } n=3\end{array}$ & $\begin{array}{c}\text { Test } \\
\text { (w/caps) } n=10\end{array}$ & $\begin{array}{c}\text { Standard } \\
\text { (no caps) } n=3\end{array}$ & $\begin{array}{c}\text { Test } \\
\text { (w/caps) } n=10\end{array}$ \\
\hline $3 \mathrm{~mm}$ & $88.6 \pm 3$ & $99.1 \pm 16$ & $2480 \pm 90$ & $3140 \pm 591$ & $21.4 \pm 1$ & $26.7 \pm 3.9$ \\
\hline $4 \mathrm{~mm}$ & $107 \pm 15.6$ & $86.3 \pm 12.5$ & $2329 \pm 179$ & $2301 \pm 130$ & $47.7 \pm 3.7$ & $47.1 \pm 2.7$ \\
\hline $5 \mathrm{~mm}$ & $77.3 \pm 2.9$ & $89.1 \pm 20$ & $1398 \pm 68$ & $2074 \pm 93$ & $55.9 \pm 2.7$ & $82.9 \pm 3.7$ \\
\hline $6 \mathrm{~mm}$ & $83.6 \pm 2.6$ & $89.9 \pm 6$ & $1639 \pm 28$ & $2333 \pm 72$ & $113 \pm 1.9$ & $161 \pm 5$ \\
\hline
\end{tabular}

Table 2. Flexural Strength, Flexural Modulus, and Slope Means 


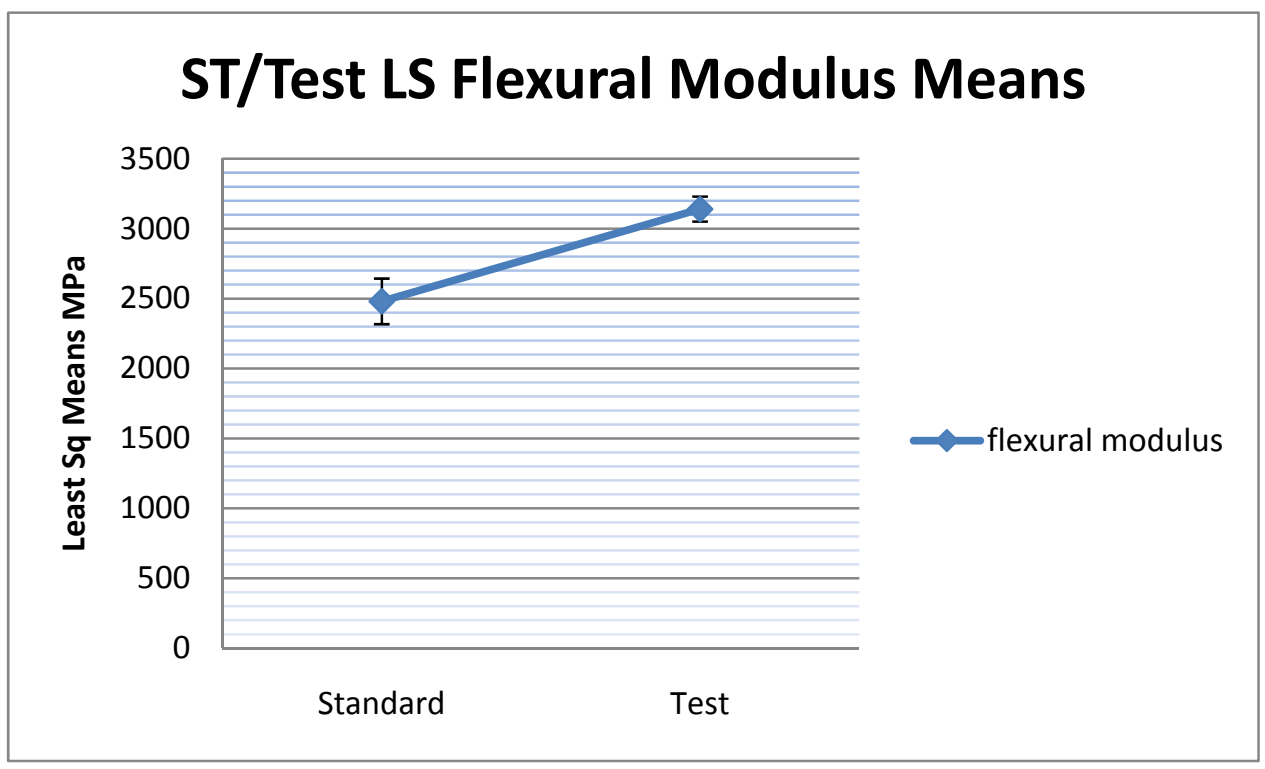

Figure 12. Standard/Test Least Sq. Flexural Modulus Means

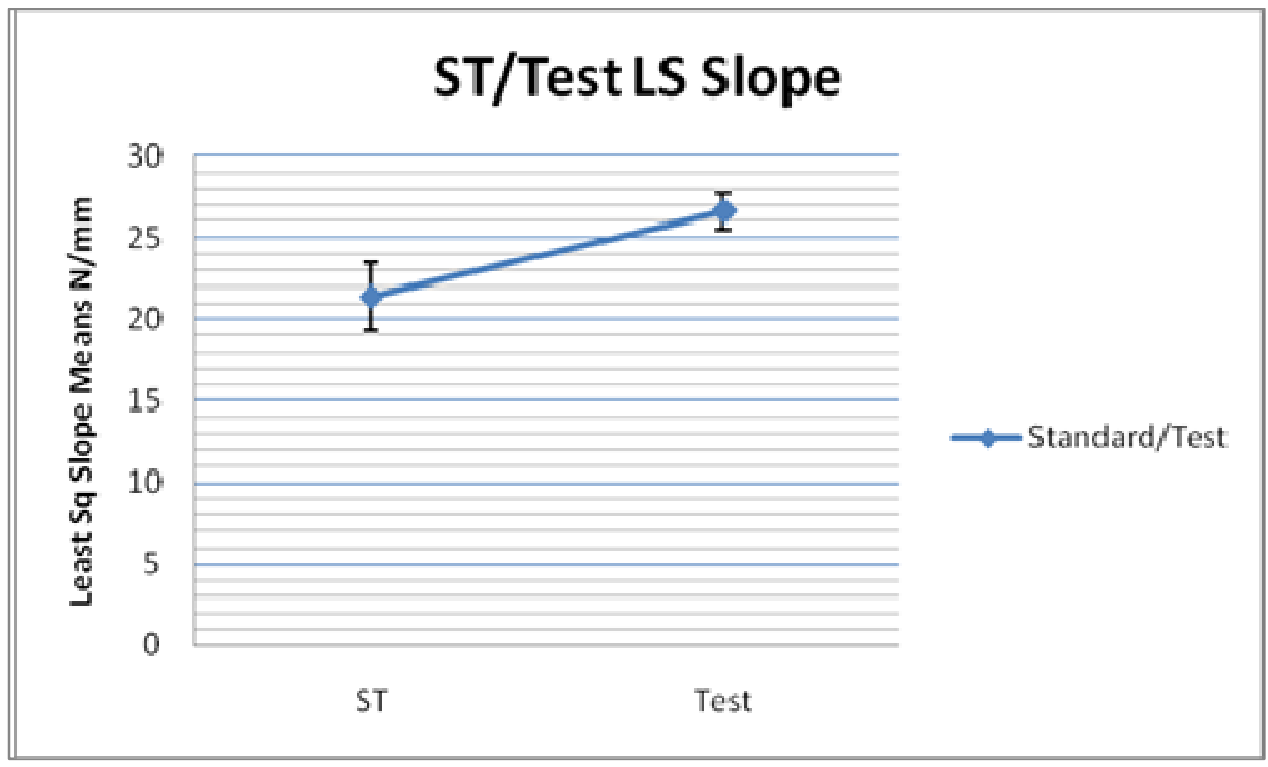

Figure 13. Standard/Test Least Sq. Slope 


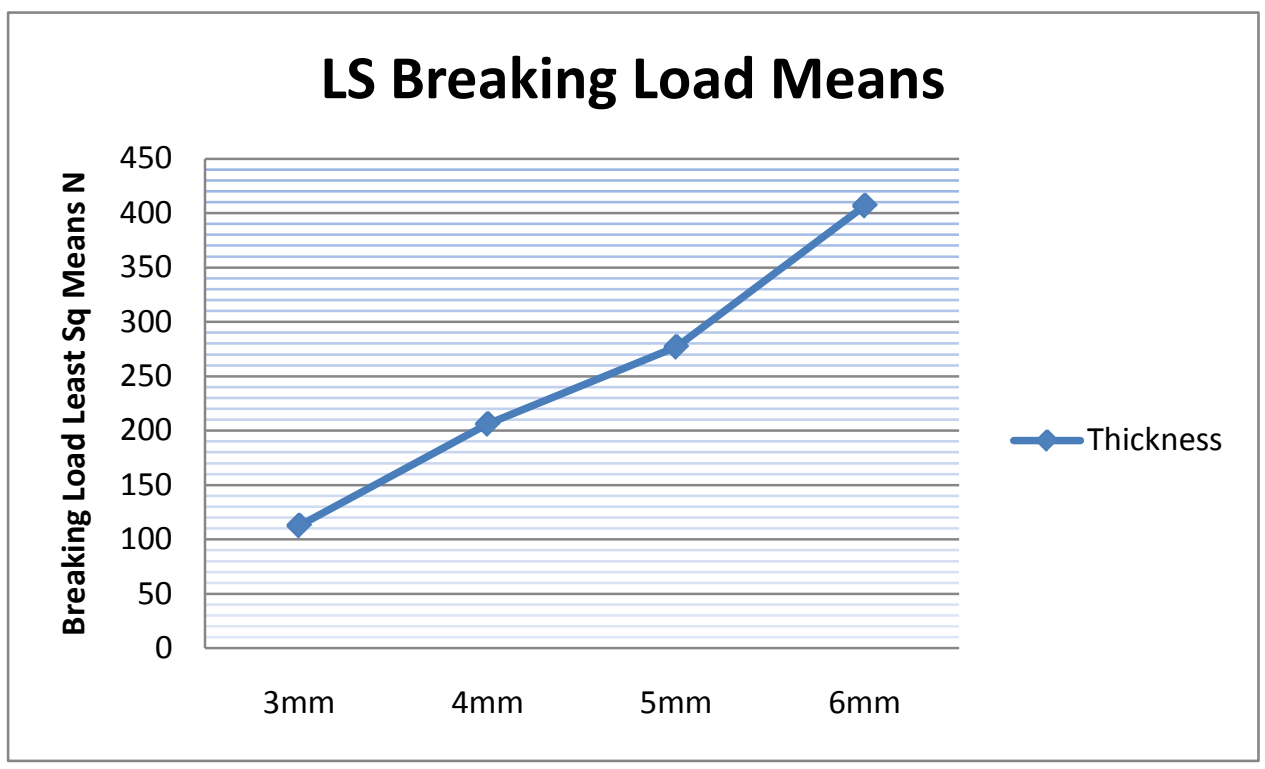

Figure 14. Breaking Load Least Sq. Means

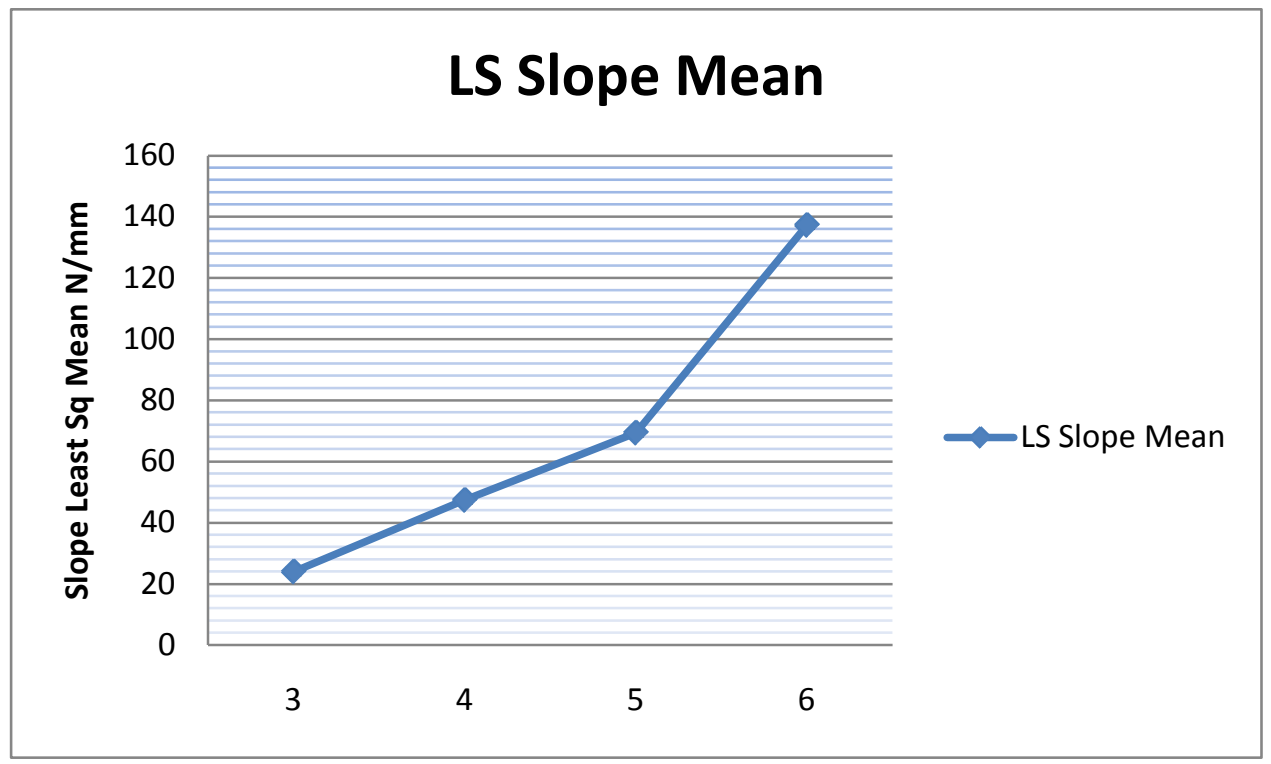

Figure 15. Slope Least Sq. Means 


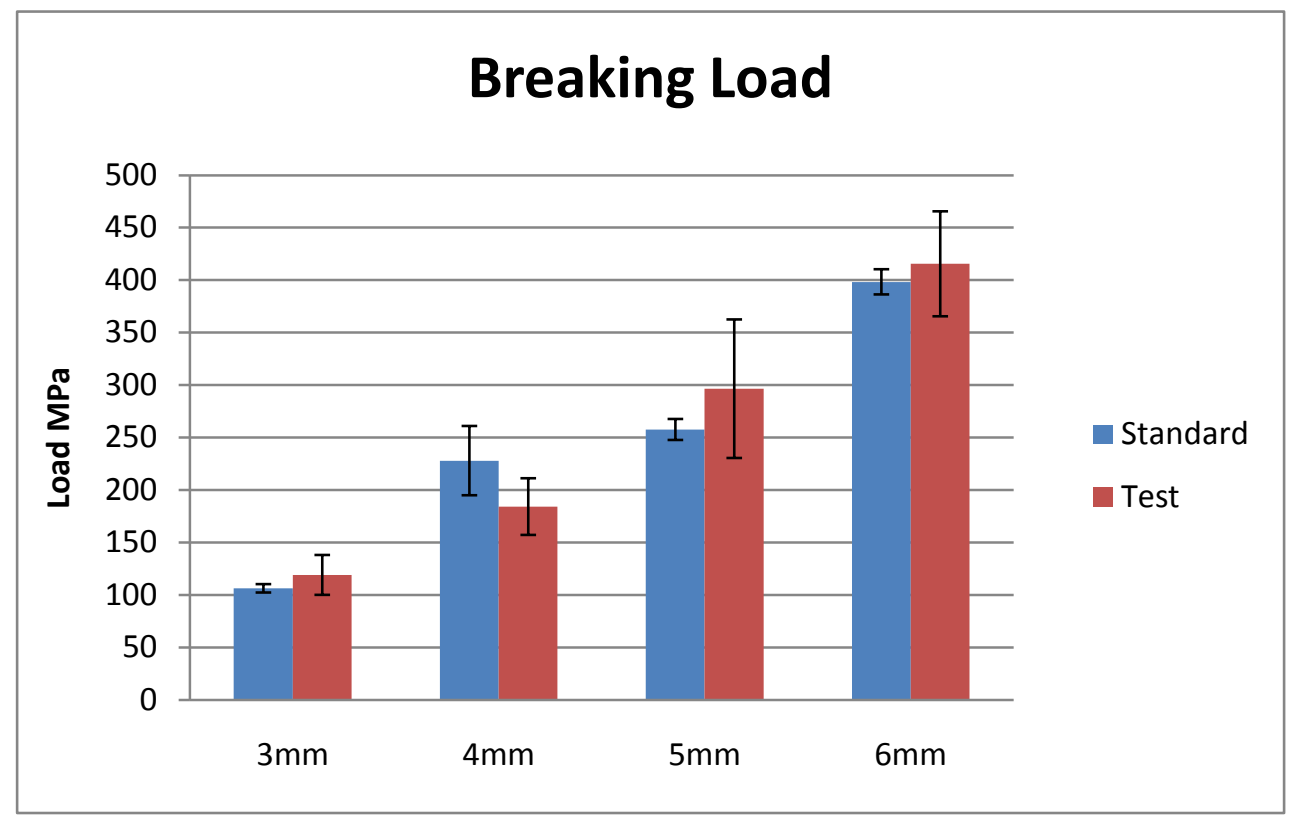

Figure 16. Breaking Load Means \pm SD

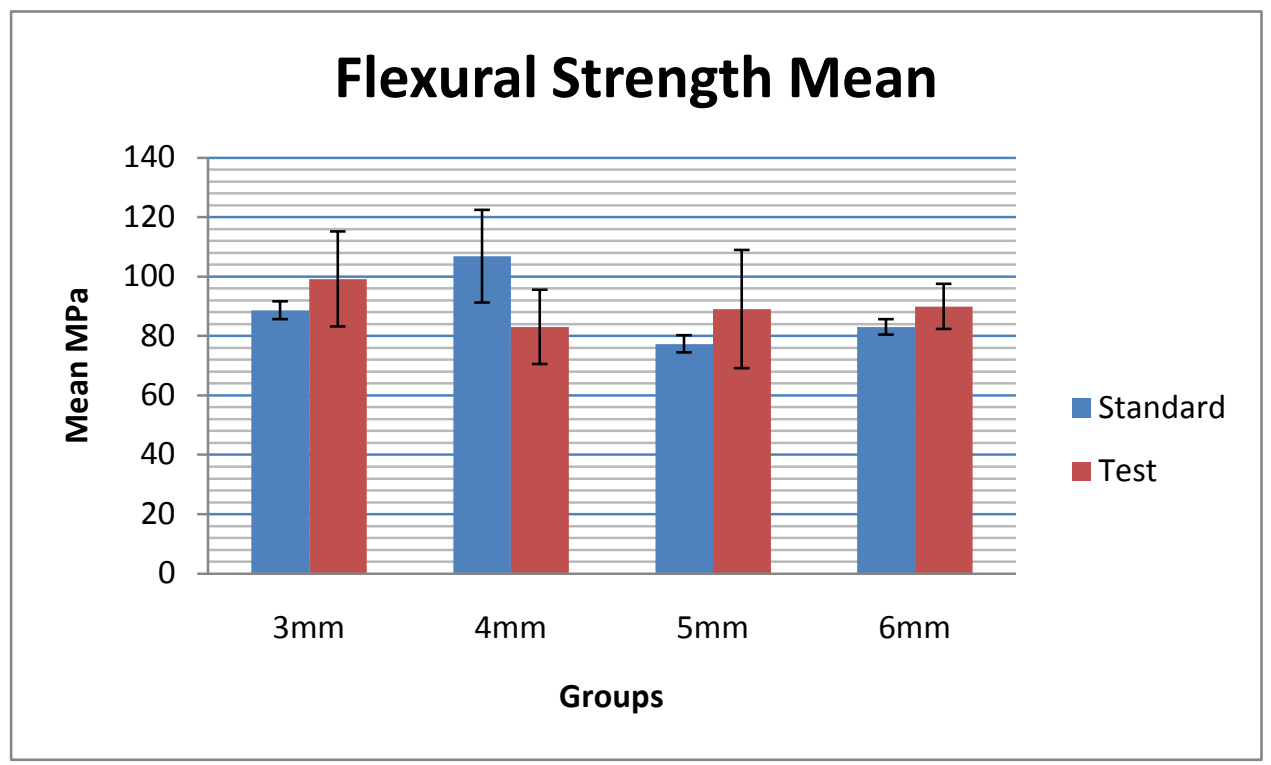

Figure 17. Flexural Strength Means \pm SD 


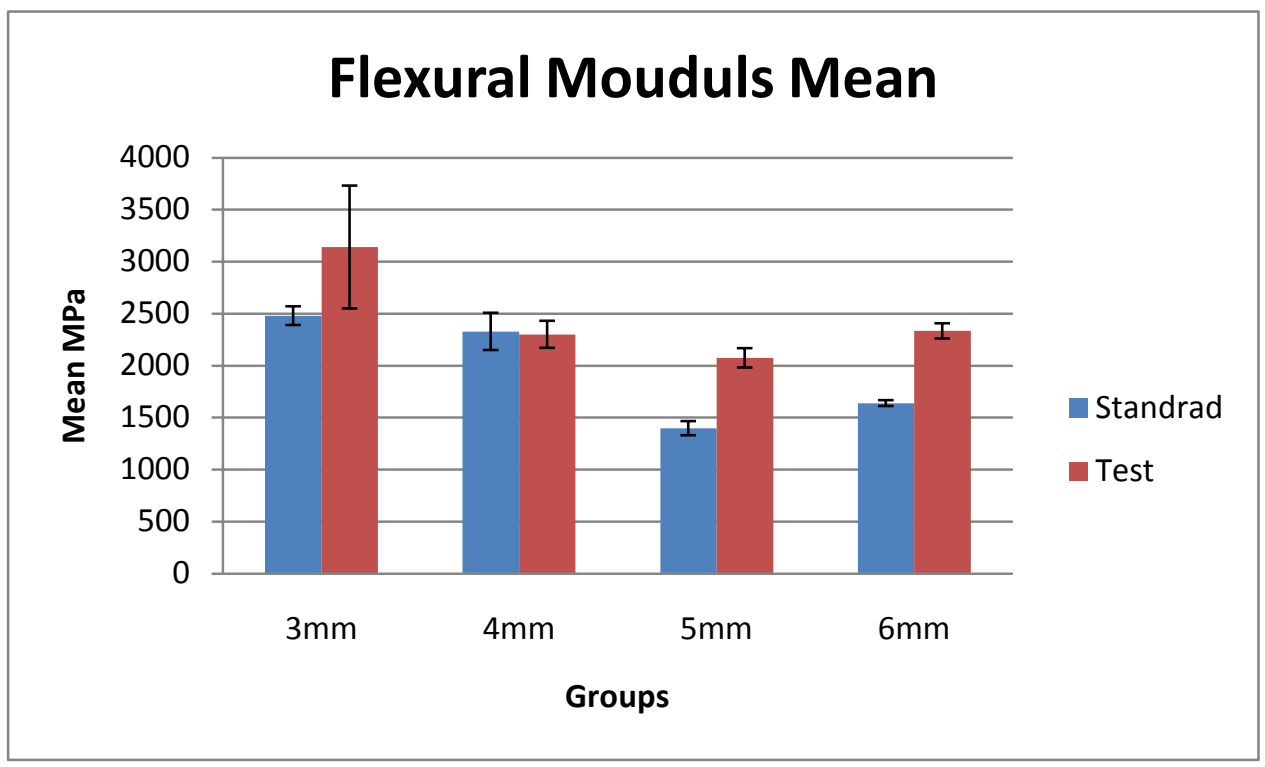

Figure 18. Flexural Modulus Means \pm SD

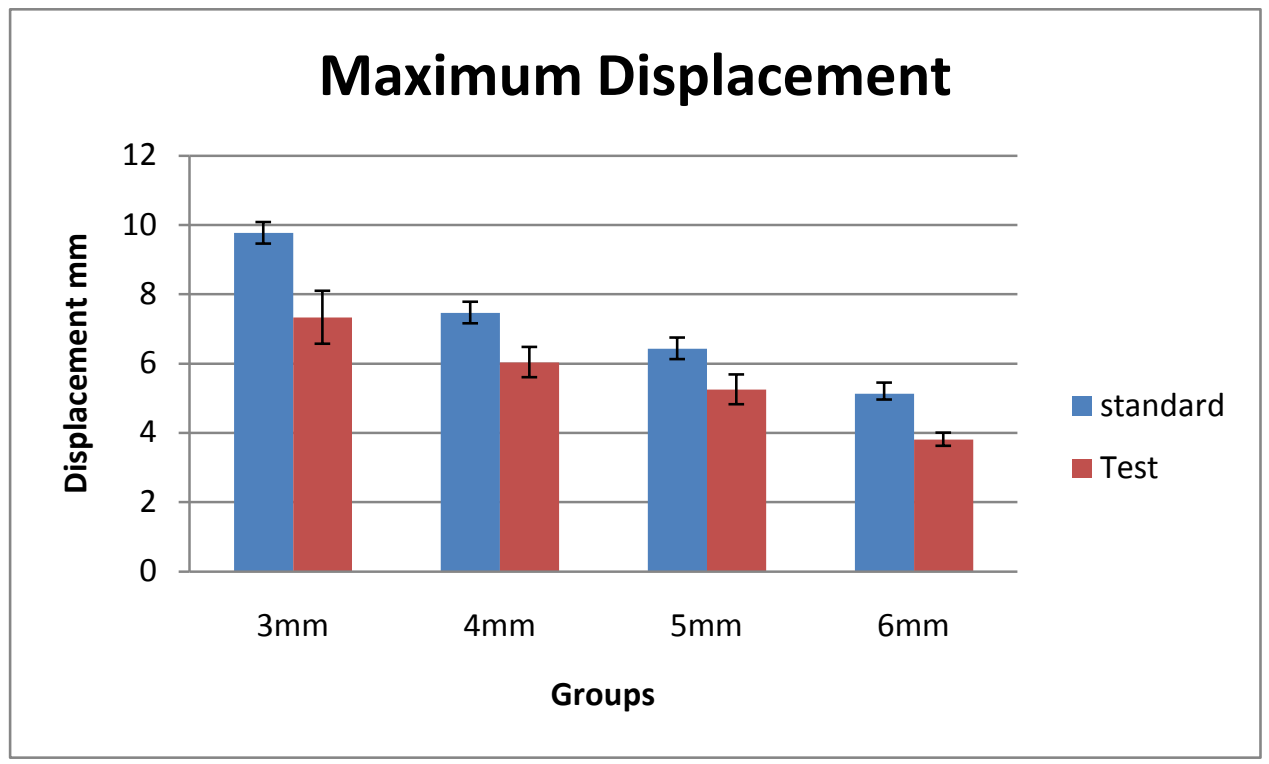

Figure 19. Maximum Displacement \pm SD 


\section{Discussion}

The fracture of acrylic resins in dentures has been a continuing problem in removable prosthesis despite numerous attempts to determine its causes. Such failure is probably due to multiple factors rather than the intrinsic properties of the denture base material alone. An analysis of the clinical situation of denture fractures shows failure result from a large transitory force caused by accident or by low and repetitive stresses inside the mouth that lead to material fatigue.

Flexural failure of denture base materials is considered the primary mode of clinical failure and has been explained by the development of microscopic cracks in the areas of stress concentration. With continued loading, these cracks fuse to an growing fissure that weakens the material. Catastrophic failure results from a final loading cycle that exceeds the mechanical capacity of the remaining sound portion of the material.

Fractures of overdentures retained by implants tend to occur where there is a concentration of stress, usually over the implant. According to Goodacre et al, fractures of implant overdentures and resin prosthesis bases occur in $12 \%$ of the prostheses. In 10 reported studies, 69 of $570(12 \%)$ overdentures have been fractured due to insufficient denture base thickness. Walton et al reported that $5.8 \%$ of removable implant-supported prosthesis repairs $(n=137)$ involved fractures in the acrylic resin. ${ }^{71,72,73 .}$ Chaffee et al, reported that 4 of 58 patients (6.9\%) required 12 mandibular overdenture repairs due to resin fracture. ${ }^{73,74}$

The purpose of this study was to investigate the effect of different acrylic resin thicknesses on the maximum breaking load, flexural strength and flexural modulus of 
denture base acrylic resins overlying the implant overdenture attachments. The null hypothesis tested was one millimeter of heat polymerize high impact denture base acrylic thickness overlaying implant stud attachment components will not meet the ANSI/ADA specification No. 12:2002/ISO 1567:1999 specification for denture base acrylic. In order to investigate the hypothesis, the three point bending flexural test was used according to the International Standard Organization (ISO 1567) recommendation for denture base polymer tests.

The data collected support rejection of the null hypothesis. The one-millimeter denture base thickness overlaying the implant stud attachment component did meet the minimum requirements for flexural strength (65 MPa) and flexural modulus (2000 MPa). Results showed that there was a positive effect with the use of Locators caps in test specimens (with Locator caps) on the flexural modulus and maximum displacement. Test specimens (with Locator caps) exhibited higher flexural modulus and lower displacement when compared to the standard specimens (no Locator caps). Such results indicate that Locator caps increased the specimens' stiffness and rigidity against high loads. In addition, there was a positive correlation between the specimen acrylic thickness and the maximum load of the test specimen (with Locator caps) gropus. In comparison between the different thickness groups of the test specimens, it was evident that the specimens withstood more load before fractures as the thickness of the Locator test specimen increased as well as reduction in the maximum displacement at fracture. However, there was no significant effect of Locator caps on the flexural strength or flexural modulus of the test specimens when compared in different thicknesses. The mean flexural strength values for the specimen groups were comparable to the 
manufacturer's claims (88.9 vs. $90 \mathrm{MPa}$ ), and the values obtained for flexural modulus were comparable for the standard groups (2480 vs. $2510 \mathrm{MPa}$ ) and higher for the locator test groups (3140 vs.2510 MPa). Overall, all testing Locator groups fulfilled the minimum requirement of the ADA/ANSI specification \#12 for denture base resin for flexural strength (65 MPa) and Flexural modulus (2000 MPa).

In vitro studies are limited in predicting the success of a material properties or technique in clinical use. There are limitations for this study that probably affected the judgment of the null hypothesis. The three points bending flexural test that was recommended by the ADA/ANSI \#12 and ISO 1567 subjected the $3 \mathrm{~mm}$ specimen groups to extended flexing. This was due to the recommended $50 \mathrm{~mm}$ lower anvil distance that supports the specimens. Such long span support did allow the specimens to accept more load and displacement due to the ability to flex (Figure 8). Such results do not reflect the real life clinical situations. Since implant-retained overdentures are supported by denture bearing area and the implant. In addition, the use of a simple rectangular shaped specimen rather than a complex denture design, as well as the absence of longer periods of water storage or cycling forces, were limitations of the study. Fatigue testing of the denture base materials under dynamic loading using the denture base configurations in simulated oral conditions, using saliva or its substitutes is recommended for future research. Well-controlled clinical studies and further in vitro studies are necessary to correlate the findings and examine those variables that influence the fatigue behavior of the denture polymers. Although the samples were prepared according to the standards with high degree of reproducibility, the results are bound to vary if any of the variables are altered. 
This study did demonstrate higher breaking load and flexural strength with increased thickness of acrylic resin over the Locator housing. Clinical experience has demonstrated problems of breakage when insufficient acrylic overlays the attachment components. Authors have recommended a minimum of $2 \mathrm{~mm}$ of acrylic resin to be sufficient to withstand oral functions and fatigue. This study cannot verify this recommendation but does indicate that greater thicknesses of acrylic resin will help to protect from resin fracture. Finite studies with clinically appropriate models are recommended for future research. 


\section{CHAPTER V}

\section{Summary}

The purpose of this study was to investigate the effect of acrylic resin thickness on the maximum breaking load, flexural strength and flexural modulus of denture base acrylic resins overlying the implant overdenture attachments.

Fifty-two rectangular specimens were fabricated from high impact denture acrylic resin (Lucitone 199). Forty specimens contained 2.00mm height Locator attachment denture caps with black processing males, 12 specimens did not include the denture cap. All specimens were fabricated according to ANSI/ADA specification \#12-2002 for testing denture base resin with constant measurements of $64 \mathrm{~mm}$ in length, $10 \mathrm{~mm}$ in width, and variable testing thickness. The specimens were divided into four testing groups according to different thickness of $3,4,5$, and $6 \mathrm{~mm}$. each group had 10 specimens with denture cap and 3 specimens without denture cap. Specimens were subjected to 3 point-bending flexural test till fracture using an Instron Universal testing machine. Data were collected for each specimen group and statistically analyzed.

The data collected from this study showed a positive effect with the use of Locators caps in test specimens on the flexural modulus and maximum displacement. Results showed a positive relationship between maximum load, maximum displacement at break and acrylic thickness. There was no significant effect of different acrylic thicknesses on the flexural strength or flexural modulus. 
From the data collected and results in this study, it can be concluded that the null hypothesis is rejected. The one-millimeter denture base thickness overlaying the implant stud attachment housing, did meet the minimum requirements for flexural strength (65 MPa) and flexural modulus (2000 MPa).

\section{Conclusions}

Within the limitations of this study, results lead to the following conclusions:

1. Evaluation of the available interarch distance, proper diagnosis, and treatment planning is of critical importance to minimize prosthesis complications and failure.

2. Implant-retained overdentures utilizing a low profile stud attachment is an acceptable treatment option for patients with compromised interarch space.

3. Implant stud attachment component integrated in specimens has a positive effect on the flexural modulus. The stiffness of the specimens increased when Locator caps were contained in the specimens compared to specimens with no caps.

4. There is positive effect of specimen thickness on the maximum load at break and maximum displacement. Increase acrylic thickness will lead to higher maximum load and decreased incidence of overdenture fractures. 


\section{References}

1. Academy of Prosthodontics: Glossary of prosthodontic terms. J Prosthet Dent 2005;94:10-92

2. Marcus SE, Drury TF, Brown LV, et al: Tooth retention and tooth loss in the permanent dentition of adults: United States 1988-1991. J Dent Res 1996;75:684-695

3. US Centers for Disease Control: Total tooth loss among persons aged $>65$ years-Selected States 1995-97. Morbidity and Mortality Weekly Report 1999; 48:206-210

4. Bouma J, Uitenbroek D,Westert G, et al: Pathways to full mouth extraction. Community Dent Oral Epidemiol 1987;15:301-305

5. Zarb GA, Schmitt A: The longitudinal clinical effectiveness of osseointegrated dental implants: The Toronto study. Part II: The prosthetic results. J Prosthet Dent 1990;64:53-61

6. Redford M, Drury TF, Kingman A, et al: Denture use and the technical quality of dental prostheses among persons 18-74 years of age: United States, 19881991. J Dent Res 1996;75:714-725

7. Smedley TC, Friedrichsen SW, Cho MH: A comparison of self-assessed satisfaction among wearers of dentures, hearing aids, and eyeglasses. $J$ Prosthet Dent 1989;62:654-661

8. Berg E: Acceptance of full dentures. Int Dent J 1993;43:299-306

9. Awad MA, Lund JP, Dufresne E, Feine JS. Comparing the efficacy of mandibular implant-retained overdentures and conventional dentures among middle-aged edentulous patients: satisfaction and functional assessment. Int J Prosth 2003; 16:117-22.

10. Meijer HJ, Raghoebar GM, Van't Hof MA. Patient satisfaction with mandibular implant overdentures and conventional dentures: a 10-year prospective study 
of clinical aspects and patient satisfaction. Int J Oral Maxillofac Implants 2003; 18:879-85.

11. Burns DR, Unger JW, Elswick RK, et al: Prospective clinical evaluation of mandibular implant overdentures. Part I: Retention, stability and tissue response. J Prosthet Dent 1995;73:354-363

12. Gotfredsen K, Holm B. Implant-supported mandibular overdentures retained with ball or bar attachments: a randomized prospective 5-year study. Int $\mathrm{J}$ Prosthodont 2000;13:125-30

13. Jemt T, Chai J, Harnett J, Heath MR, Hutton JE, Johns RB, et al. A 5-year prospective multicenter follow-up report on overdentures supported by osseointegrated implants. Int J Oral Maxillofac Implants 1996; 11:291-8.

14. Van Kampen F, Cune M, van der Bilt A, Bosman F. Retention and postinsertion maintenance of bar-clip, ball and magnet attachments in mandibular implant overdenture treatment: an in vivo comparison after 3 months of function. Clin Oral Implants Res 2003; 14:720-6.

15. Ambard AJ, Fanchiang JC, Mueninghoff L, Dasanayake AP. Cleansability of and patients' satisfaction with implant-retained overdentures. J Am Dent Assoc 2002; 133:1237-42.

16. Misch CE. Treatment options for mandibular implant overdenture: An organized approach. In: Contemporary implant dentistry, 2nd ed. St. Louis: Mosby; 1998. p. 175-92.

17. K, Wong KM. Space requirements for implant-retained bar-and clip overdentures. Compend Contin Educ Dent 2001; 22:516-22.

18. Cornell K. Lee. Surgical and prosthetic planning for a two-implant-retained mandibular overdenture: A clinical report. J Prosthet Dent 2006;95:102-5

19. Nopsaran Chaimattayompol, Assessing the space limitation inside a complete denture for implants attachments. J Prosthet Dent 2003;89:82-5

20. Isma Liza Ali, MClinDent. Hardness, Flexural Strength, and Flexural Modulus Comparisons of Three Differently Cured Denture Base Systems. J

Prosthodont 2008; 545-549-17. 
21. Feine JS, Carlsson GE, Awad MA, Chehade A, Duncan WJ, Gizani S, et al. The McGill consensus statement on overdentures. Mandibular two-implantoverdentures as first choice standard of care for edentulous patients. Int $\mathrm{J}$ Oral Maxillofac Implants 2002; 17:601-2.

22. Taylor TD. Indications and treatment planning for mandibular implant overdentures. In: Feine JS, Carlsson GE, editors. Implant overdentures as the standard of care for edentulous patients. Chicago: Quintessence; 2003. p. 7181.

23. Fitzpatrick B: Standard of care for the edentulous mandible: a systematic review. J Prosthet Dent 2006; 95:71-78.

24. Marianna Pasciuta, Yoav Grossmann. A prosthetic solution to restoring the edentulous mandible with limited interarch space using an implant-tissuesupported overdenture: A clinical report. J Prosthet Dent 2005;93:116-20.

25. Jemt $T$, Book K, Lindén B, Urde G. Failures and complications in 92 consesecutively inserted overdentures supported by Brånemark implants in severely resorbed edentulous maxillae: A study from prosthetic treatment to first annual check-up. Int J Oral Maxillofac Implants 1992; 7:162-167.

26. Hemmings KW, Schmitt A, Zarb GA. Complications and maintenance requirements for fixed prostheses and overdentures in the edentulous mandible: a 5-year report. Int J Oral Maxillofac Implants 1994; 9:191-196.

27. Mericske-Stern R. Clinical evaluation of overdenture restorations supported by osseointegrated titanium implants: a retrospective study. Int J Oral Maxillofac Implants 1990; 5:375-382.

28. Gotfredsen K, Holm B. Implant-supported mandibular overdentures retained with ball or bar attachments: a randomized prospective 5-year study. Int $\mathrm{J}$ Prosthodont 2000; 13:125-130.

29. Johns RB, Jemt T, Heath MR, Hutton JE, McKenna S, McNamara DC, van Steenberghe D, Taylor R, Watson RM, Herrmann I. A multicenter study of overdentures supported by Brånemark implants. Int J Oral Maxillofac Implants 1992; 7:513-522. 
30. Wismeyer D, van Waas MAJ, Vermeeren JIJF. Overdentures supported by ITI implants: A 6.5-year evaluation of patient satisfaction and prosthetic aftercare. Int J Oral Maxillofac Implants 1995; 10:744-749.

31. Cooper LF, Scurria MS, Lang LA, Guckes AD, Moriarty JD, Felton DA. Treatment of edentulism using Astra Tech implants and ball abutments to retain mandibular overdentures. Int J Oral Maxillofac Implants 1999; 14:646653.

32. Allen PF, McMillan AS, Smith DG. Complications and maintenance requirements of implant-supported prostheses provided in a UK dental hospital. Br Dent J 1997; 182:298-302.

33. Davis DM, Rogers JO, Packer ME. The extent of maintenance required by implant retained mandibular overdentures: a 3-year report. Int J Oral Maxillofac Implants 1996; 11:767-74.

34. Cooper LF. The Current and Future Treatment of Edentulism. J Prosthodont 2000;116-122-18.

35. Felton D. Edentulism and Comorbid Factors. J Prosthodont 2009;88-96-18.

36. Ellis JS, Pelekis ND, and Thomason JM: Conventional rehabilitation of edentulous patients: the impact on oral health-related quality of life and patient satisfaction. J Prosthodont 2007; 16:37-42.

37. McGrath C, Bedi R: Population based norming of the UK oral health-related quality of life measure. Br Dent J 2002; 193:521-524.

38. Yoshida $Y$, Hatanaka $Y$, Imaki M, et al: Epidemiological study on improving the QOL and oral conditions of the aged. Part 1: the relationship between the status of tooth preservation and QOL. J Physiol Anthropol Appl Human Sci 2001; 20:363-368.

39. Locker D, Matear D, Stephens M, et al: Oral health-related quality of life of a population of medically compromised elderly people. Community Dent Health 2002; 19:90-97. 
40. Lund JP: Introduction: it is time to tackle denture disability. In Feine JS, Carlsson GE (eds): Implant Overdentures: The Standard of Care for Edentulous Patients. Carol Stream, IL,Quintessence, 2003, p. 1.

41. Fiske J, Davis DM, Frances C, et al: The emotional effects of tooth loss in edentulous people. Br Dent J 1998; 184:90-93; discussion 79.

42. Chauncey HH, Muench ME, Kapur KK, et al: The effect of the loss of teeth on diet and nutrition. Int Dent J 1984; 34:98-104.

43. Mignogna MD, Fedele S: The neglected global burden of chronic oral diseases. J Dent Res 2006; 85:390-391.

44. Petersen PE, Bourgeois $\mathrm{D}$, Ogawa $\mathrm{H}$, et al: The global burden of oral diseases and risks to oral health. Bull World Health Org 2005;83:661-669.

45. Burns DR. Mandibular Implant Overdenture Treatment:Consensus and Controversy. J Prosthet Dent 2000; 9:37-46.

46. Douglass CW, Shih A, Ostry L. Will there be a need for complete dentures in the United States in 2020? J Prosthet Dent 2002; 87:5-8.

47. Berg E, Ingebretsen R, Johnson TB. Some attitudes towards edentulousness, complete dentures and cooperation with the dentist. Acta Odontol Scand $1984 ;$ 42:334-8.

48. Oliver J Corrado. Everyday Aids and Appliances: Dentures. Br Med J 7 1990; 301:1265-8.

49. Zarb GA. The edentulous milieu. J Prosthet Dent 1983; 49:825-31.

50. Fenlon MR, Sherriff M, Walter JD: Agreement between clinical measures of quality and patients' rating of fit of existing and new complete dentures. J Prosthet. Dent 2002;30:135-139.

51. Kiyak HA, Beach BH, Worthington $\mathrm{P}$, Taylor T, Bolender C, Evans J. The psychological impact of osseointegrated dental implants. Int J Oral Maxillofac Implants 1990; 5:61-9. 
52. Geertman ME, Slagter AP, van't Hof M, van Waas MAJ, Kalk W. Masticatory performance and chewing experience with implant-retained mandibular overdentures. J Oral Rehabil 1999; 26:7-13.

53. Van waas MAJ. Determinants of dissatisfaction with dentures: A multiple regression analysis. J Prosthet Dent 1990; 64:569-72.

54. Bergman B, Carlsson GE. Review of 54 complete denture wearers patients' opinions 1 year after treatment. Acta Odont Scand 1972; 30:399-414.

55. Allen PF, McMillan AS, Walshaw D. A patient-based assessment of implant stabilized and conventional complete dentures. J Prosthet Dent 2001; 85:1417.

56. Hartsook El. Food selection, dietary adequacy, and related dental problems of patients with dental prostheses. J Prosthet Dent 1974; 32:32-40.

57. FENTON A. H.: The Decade of overdenture: 1970-1980. J. Prosthet. Dent. 79: 31-36, 1998.

58. Dostálová T.1, Radina P.1, Seydlová M.1, Zvárová J.2, Valenta Z. Overdenture - Implants versus Teeth - Quality of Life and Objective Therapy Evaluation. Prague Medical Report / Vol. 110 (2009) No. 4, p. 332-342.

59. PAVLATOS J.: The Root-supported overdenture using the locator overdenture attachment. Gen. Dent. 5: 448-453, 2002.

60. ETTINGER R. L., JOKOBSEN J. R.: A Comparison of patient satisfaction and dentist evaluation of overdenture therapy. Community Dent. Oral Epidemiol. 25: 223-227, 1997.

61. Albrektsson T, Wennerberg A. The Impact of Oral Implants — Past and Future, 1966-2042. J Can Dent Assoc 2005; 71(5):327.

62. Ring ME. A thousand years of dental implants: A definitive history - Part 1. Compendium 1995; 16:1060-1069.

63. Yanase RT, Preston JD. Nomenclature for Implant Dentistry. In Reconstructive and Preprosthetic Oral and Maxillofacial Surgery, edited by 
Fonseca R, Davis WH.Philadelphia, WB Saunders and Co, Edition 2, 1995, pp 225-249.

64. Brånemark PI, Zarb GA, Albrektsson T. Tissue Integrated Prostheses. Chicago, Quintessence Publishing Co, Inc, 1985, pp 11-76.

65. Raghoebar GM, Meijer HJA, Stegenga B, van't Hof MA, van Oort RP, Vissink A. Effectiveness of three treatment modalities for the edentulous mandible. Clin Oral Impl Res 2000; 11:195-201.

66. Tallgren A. The continuing reduction of the residual alveolar ridges in complete denture wearers: a mixed-longitudinal study covering 25 years. J Prosthet Dent 1972; 27:120-132.

67. Quirynen M, Naert I, van Steenberghe D, et al: Periodontial aspects of osseointegrated fixtures supporting a partial bridge. An up to 6-years retrospective study. J Clin Periodontol 1992; 19:118-126.

68. Naert I, Quirynen M, Theuniers G, et al: Prosthetic aspects of osseointegrated fixtures supporting overdentures. A 4-year report. J Prosthet Dent 1991; 65:671-680.

69. Kenney R, Richards MW. Photoelastic stress patterns produced by implantretained overdentures. J Prosthet Dent 1998; 80:559-564.

70. LOCATOR® IMPLANTATTACHMENT SYSTEM. http://www.raglelab.com/education/Locator_Implant\%20Attachment.pdf

71. Walton J, MacEntee M. A retrospective study on the maintenance and repair of implant-supported prostheses. Int J Prosthodont 1993; 6:451-455.

72. Walton JN, MacEntee MI. A prospective study on the maintenance of mplant prostheses in private practice. Int J Prosthodont 1997; 10: 453-8.

73. Tomoya Gonda, Yoshinobu Maeda, Joanne N. Walton. Fracture incidence in mandibular overdentures retained by one or two implants. J Prosthet Dent 2010; 103:178-181. 
74. Chaffee NR, Felton DA, Cooper LF, Palmqvist U, Smith R. Prosthetic complications in an implant-retained mandibular overdenture population: initial analysis of a prospective study. J Prosthet Dent 2002; 87:40-4.

75. . Zitzmann NU, Marinello CP. A review of clinical and technical considerations for fix and removable implant prostheses in the edentulous mandible. Int $\mathrm{J}$ Prosthodont. 2002; 15:65-72.

76. Alexander Shor, Yoshihiro Goto, Kavita Shor . Mandibular two-implantretained overdenture: prosthetic design and fabrication protocol. Compend Contin Educ Dent. 2007 Feb; 28(2):80-8; quiz 89, 101.

77. Thompson GW, Kreisel PS. The impact of the demographics of aging and the edentulous condition on the dental care service. J Prosthet Dent 1998; 97;5659.

78. Zitzmann NU, Marinello CP. A review of clinical and technical considerations for fixed and removable implant prostheses in the edentulous mandible. Int $\mathrm{J}$ Prosthodont. 2002; 15:65-72.

79. Lekholm U. Clinical procedures for treatment with osseointegrated dental implants. J Prosthet Dent. 1983; 50:116-120.

80. Salaita L, Kumar N, Kanawati M, ALawadhi K. Poster title "An analysis of functional space requirements in Implant retained mandibular overdentures" presented at WVU School of Dentistry, spring 2010.

81. American National Standards Institute (ANSI). http://www.webstore.ansi.org/

82. Meng TR, Latta MA. Physical Properties of Four Acrylic Denture Base Resins. J Contemp Dent Pract 2005 November ;(6)4:093-100.

83. Ioannis Kostoulas, Victoria T. Kavoura, Mary J. Frangou, Gregory L. Polyzois. Fracture Force, Deflection, and Toughness of Acrylic Denture Repairs involving Glass Fiber Reinforcement. J Prosthet Dent. 2008; 17:257-261. 


\section{CURRICULM VITAE}

Name:

Date of Birth:

Place of Birth:

Education:

August 2002- May 2006

July 2007 - present
Khaled N. Alawadhi D.D.S

Nov. $30^{\text {th }}, 1978$

Kuwait City, KUWAIT
West Virginia University

School of Dentistry

Morgantown, West Virginia

Doctorate of Dental Surgery

West Virginia University

School of Dentistry

Department of Graduate Prosthodontics

Morgantown, West Virginia

Master of Science (anticipated August 2010)

John $\mathrm{H}$. 